\title{
Asia-Gondwana connections indicated by Devonian fishes from Australia: palaeogeographic considerations
}

\author{
Gavin Charles Young ${ }^{1,2^{*}}$ and Jing Lu $\mathrm{Lu}^{1,3,4}$
}

\begin{abstract}
Middle Palaeozoic vertebrate fossil occurrences are summarised for Australia, with reference to faunal connections between Asia and East Gondwana, as first indicated by fish distributions of Lower Devonian fossil sites. Major endemic groups discussed are pituriaspid (Australian) and galeaspid (Asian) agnathans, wuttagoonaspids (Australian) and antarctaspid (Antarctic, Australian, Asian) arthrodires, yunnanolepid and sinolepid antiarchs (South China, Indochina terrane, Australia), and early tetrapodomorphs (South China, Australia). More widespread groups that lived in shallow marine environments (lungfishes, buchanosteid arthrodires, antiarch Bothriolepis) also show species groups shared between South China and East Gondwana. Exchange of continental facies fishes (e.g. tristichopterid tetrapodomorphs) may have been interrupted by marine transgression in the Frasnian, but were restored in the late Famennian with the appearance of Grenfellaspis in eastern Australia, the only sinolepid antiarch known from outside Asia. The hypothesis of Gondwana dispersion and Asian accretion, to explain the collage of geological terranes forming modern east and southeast Asia, implies increasing dissimilarity with increasing age, but the SiluroDevonian early vertebrate evidence is inconsistent with this. Previous cladistic analysis of Asian terranes predicted galeaspid agnathans on the Indochina terrane, and their subsequent discovery at Ly Hoa, Vietnam, confirms that Indochina and South China had come together across the Song Ma suture by Middle Devonian time.
\end{abstract}

Keywords: Devonian, Palaeogeography, Biogeography, Vertebrates, East Gondwana, South China, Indochina terrane

\section{Introduction}

The Devonian Period is widely known as the 'Age of Fishes', because for the first time in the fossil record there were abundant and diverse remains of early vertebrates. In fact, it was an isolated scale of the Upper Devonian lobe-finned fish Holoptychius, identified by Louis Agassiz in 1840 from supposedly 'Silurian' strata in Belgium (later described by Agassiz 1844), that proved decisive evidence for correlating between marine strata in Devon, England, and the well-known 'Old Red Sandstone' of Scotland (Rudwick 1985). This and other evidence led to Sedgwick and Murchison (1839) erecting

\footnotetext{
*Correspondence: Gavin.Young@anu.edu.au

'Department of Applied Mathematics, Research School of Physics, Australian National University, Canberra, Australia

${ }^{2}$ Australian Museum Research Institute, Sydney, Australia

Full list of author information is available at the end of the article
}

the Devonian System, to fill a gap in the stratigraphic succession above the Silurian of Murchison (1839) and beneath the Carboniferous of Conybeare and Phillips (1822) for the British 'Coal Measures', which then also included the Devonian Old Red Sandstone. In the subsequent 180 years, Devonian fish fossils have been found in sedimentary rocks throughout the world, in a wide range of lithologies representing all habitable aquatic environments, from marine to estuarine, fluviatile and lacustrine.

First discoveries in the Southern Hemisphere included bones (probably belonging to the antiarch placoderm Remigolepis) from Twofold Bay on the coast of southeastern Australia (Clarke 1860; Young 2007), a skull from Burrinjuck, New South Wales, and fish scales and bones from Antarctica collected on Scott's 1910-1913 
South Pole Expedition (Woodward 1916, 1921). Today these sites are among numerous Devonian fossil fish localities representing the East Gondwanan region (Australasia-Antarctica). In Asia, Mansuy (1907, 1915) first recorded Devonian fish remains from China and northern Vietnam respectively, now extensively documented in the Siluro-Devonian of the South China Block (Zhao and Zhu 2010) as one of the three greatest endemic biological radiation episodes in the entire evolutionary history of the vertebrates (e.g. Zhu et al. 2009, 2013, 2016).

This paper presents an overview of Middle Palaeozoic vertebrate fossils from East Gondwana that provide evidence of faunal connections with the various Asian palaeo-blocks and terranes identified for the SilurianDevonian. Figure 1 summarises 44 generalised Devonian fish localities for Australia-Antarctica (see also Burrow et al. 2010, fig. 4, for localities represented by Devonian vertebrate microfossils). Zhao and Zhu (2010, fig. 1) provided a comparable summary of 74 Siluro-Devonian fish localities across China, and Wang et al. (2010a, fig. 1) showed 18 fish localities across southeast Asia.

In general terms, the vertebrate fossil record from the Ordovician to the Devonian is concerned with two major aquatic groups: the fish-like agnathans (jawless vertebrates), and fishes with jaws (primitive gnathostomes). This evolutionary phase ended with the emergence of terrestrial vertebrates, for which a minimum age of Early Devonian is provided by the fossil record (both tetrapod body fossils, and trackway evidence). Other evidence (e.g. diversity modelling of genus-level preservation rates; molecular data) does not exclude an even older (Silurian) age for tetrapod origins (Friedman and Brazeau 2011; George and Blieck 2011), as had been previously suggested from phylogenetic and trace fossil considerations (Chang 1991; Young 2006). The aquatic habitat of fishes, which are tied to environments of deposition rather than erosion, gives them a better chance of preservation as fossils than terrestrial vertebrates. The robust bones of the most diverse Devonian group, the extinct placoderms or 'armoured fishes' (Young 2010a), provides a highly complex data set such that their distributions in time and space can be applied to questions of Middle Palaeozoic palaeogeography (e.g. Zhu and Young 2010).

The importance of freshwater fish distributions for modern biogeographic studies of continental faunas is well established (e.g. Berra 1981), but whether it is reasonable to extrapolate back into the Palaeozoic has been questioned. In commenting on Devonian vertebrate evidence, for example, the generalisation that 'fish could swim' (Hurley and Van Der Voo 1987, p. 144) was considered to limit the value of fossil evidence compared to other palaeogeographic data (e.g. palaeomagnetism).
Thus, the dispersal capabilities of Devonian fishes have been widely considered regarding reconstructions of past geography, in particular how to distinguish between two groupings: i) 'primary division' fishes (entirely restricted to freshwater), and ii) fishes with some tolerance of marine environments, or which entered the sea during parts of their life cycles. Detailed analysis of depositional environments has not resolved this problem; even if adults of certain fossil species are only found in marginal marine or non-marine deposits, the dispersal capacity of larval forms cannot be known. These are questions about processes, which are difficult or impossible to deal with in historical science as testable hypotheses. Yet the same difficulties apply to experimentation on living fish species, for example to establish saltwater tolerance and dispersal capabilities to explain disjunct distributions (e.g. dispersal history of modern galaxiid fishes across the southern continents).

An alternative approach concerns analysis of pattern, whereby two ecological groupings of fishes are considered relevant to biogeographic studies (Rosen 1974): 'continental' (freshwater, marginal and shallow marine forms of continental shelves), and 'oceanic' (pelagic forms of the open oceans). These are identified by biogeographic analysis of distribution patterns in relation to phylogeny. From this perspective, some compelling inferences can be drawn from the global distribution patterns of major fish taxa recorded from Devonian rocks. Thus, Young (1981) identified five faunal provinces based on the presence or absence of major groups: Cephalaspid Province (Laurussia), Amphiaspid Province (Siberia), Tannuaspid Province (Tuvan massif), Galeaspid-Yunnanolepid Province (South China), and Wuttagoonaspid-Phyllolepid Province (East Gondwana). The last two provinces and their inter-connections are the topic of this paper.

Regarding palaeogeographic connections between East Gondwana and other areas, Middle Palaeozoic vertebrate evidence has highlighted two major data conflicts. Strongly endemic Early Devonian faunas in East Gondwana indicate isolation, but with increased cosmopolitanism during the Middle Devonian, and strong evidence by the Late Devonian of faunal exchange with the Laurussian palaeocontinent (e.g. antiarch placoderms such as Bothriolepis widespread across both regions; the arthrodire Groenlandaspis antarctica occurring in non-marine deposits in both Greenland and Antarctica). This is contradicted in some palaeomagnetic reconstructions that indicate just the reverse; i.e. proximity between Gondwana, Laurentia, and Baltica in the Early Devonian, and Gondwana widely separated from Laurussia by an equatorial ocean in the Late Devonian (e.g. McElhinney et al. 2003, fig. 6f-h).

The second issue concerns Gondwana dispersion and Asian accretion (e.g. Metcalfe 1996a, 1996b, 2013), also 


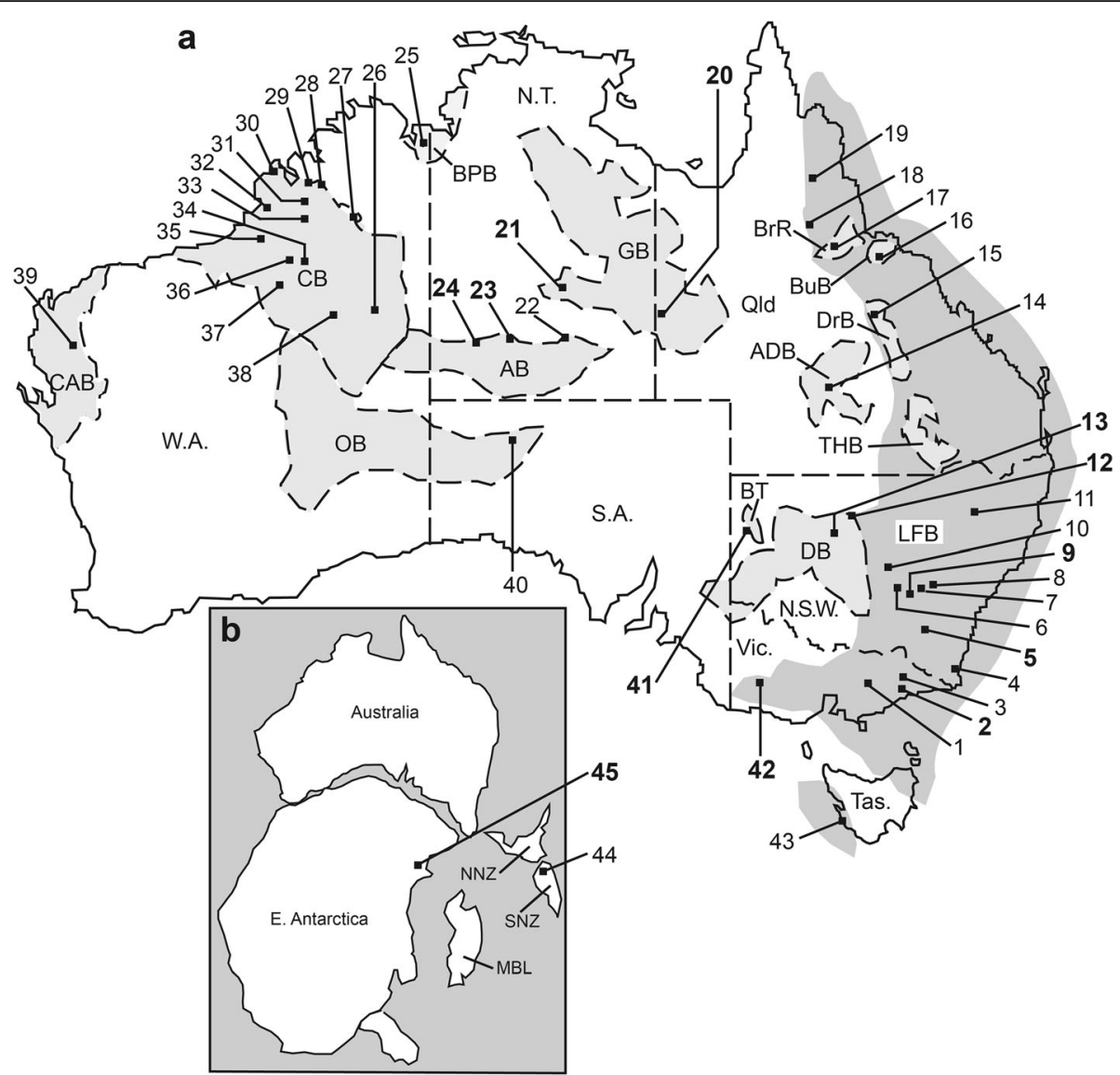

Fig. 1 Generalised Devonian vertebrate fossil localities for East Gondwana (updated from Young et al. 2010, fig. 1). a Australian localities numbered from the southeast in an anticlockwise direction; b Devonian reconstruction of Australia, East Antarctica and New Zealand showing additional localities in New Zealand (44) and southern Victoria Land, Antarctica (45). Abbreviations for regions, Australian states, etc. are: MBL= Marie Byrd Land (West Antarctica); NNZ= New Zealand north island; N.S.W.= New South Wales; N.T.= Northern Territory; Qld= Queensland; S.A.= South Australia; SNZ= New Zealand south island; Vic.=Victoria; W.A.= Western Australia; Tas.= Tasmania. Abbreviations for Australian geological provinces and sedimentary basins (shaded areas) are: $A B=$ Amadeus Basin; $A D B=$ Adavale Basin (subsurface Devonian); $B P B=$ Bonaparte Basin; $\mathrm{BrR}=$ Broken River Province; $\mathrm{BT}=$ Bancannia Trough (subsurface Devonian); $\mathrm{BuB}=$ Burdekin Basin; $\mathrm{CB}=\mathrm{Canning} \mathrm{Basin} ; \mathrm{CAB}=$ Carnarvon Basin; $\mathrm{DB}=$ Darling Basin; $\mathrm{DrB}=$ Drummond Basin; $\mathrm{GB}=$ Georgina Basin; $\mathrm{LFB}=$ Lachlan Fold Belt; $\mathrm{OB}=$ Officer $B a s i n ; \mathrm{THB}=$ Timbury Hills Basin (subsurface Devonian). For details of all localities see Young et al. (2010). Details for localities discussed or mentioned in this paper (shown in bold) are: 2, Buchan/Bindi, Gippsland, Victoria; 4, Twofold Bay, NSW south coast; 5, Taemas/Wee Jasper (Burrinjuck) limestones; 9 , Grenfell-Bumberry syncline area; 12, Gunderbooka/Cobar; 13, Wuttagoona/ Tambua/Mt. Jack; 20, Toomba Range/Cravens Peak; 21, Dulcie Range; 24, Mount Winter; 40, Munyarai 1 well, Officer Basin; 41, western Darling Basin (Barrier Range, Mutawintji); 42, Grampians, western Victoria; 45, Aztec fish assemblage, Skelton Neve and Cook Mountains areas, Transantarctic Mountains, southern Victoria Land

supported by some palaeomagnetic (e.g. Zhao et al. 1996; Yang et al. 2004) and other data (Wang et al. 2010b; Duan et al. 2011). This proposed that South China, and perhaps North China and various parts of south-east Asia, were attached to the northern Gondwana margin in the Early Palaeozoic, but by the Mid-Late Devonian had separately moved away, to eventually form the collage of geological terranes making up modern Asia. Under that scenario, the further back in time, the greater should be dissimilarities between the Asian tectonic blocks and terranes. However, as previously noted by Young and Janvier (1999), SiluroDevonian distribution patterns for fossil vertebrates across Asia suggested the opposite, being more consistent with modern geography than with the model of widely dispersed Asian terranes. Zhao and Zhu (2010, figs. 2, 6) show various Asian blocks and terranes closely associated or connected from the Silurian onward, together representing a 'Pan-Cathaysian landmass' defined by galeaspid agnathans (jawless vertebrates). This issue is further considered below, following a brief overview of Gondwana vertebrates relevant to connections with Asia in the Siluro-Devonian. Some agnathans and placoderms are illustrated in Figs. 2, 3 and 4, and the temporal-spatial distribution of selected placoderm groups is summarised in Fig. 5. Osteichthyans are illustrated in Figs. 6 and 7 and 


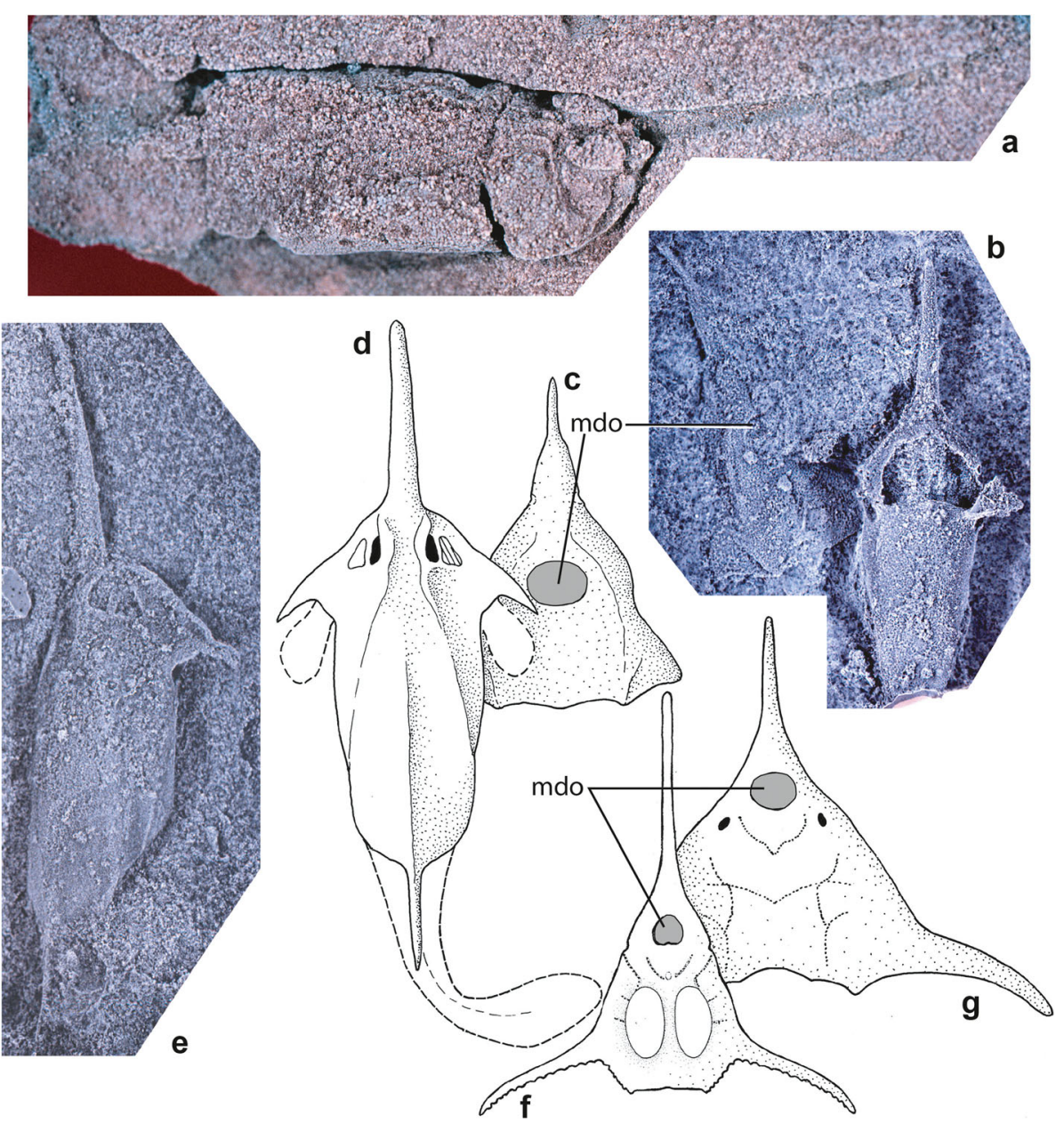

Fig. 2 The only armoured agnathans known from Gondwana (a-e) compared with some from Asia (f and $\mathbf{g})$. Pituriaspis (a, b right side, $\mathbf{d}$ and $\mathbf{e}$ ) and Neeyambaspis (b left side, c), as described by Young (1991) from the Georgina Basin (localities 20-21, Fig. 1); c and d reconstructions of Neeyambaspis (c) and Pituriaspis (d) in dorsal view (d based on $\mathbf{e}$ ); $\mathbf{f}$ and $\mathbf{g}$ comparison with two galeaspids from South China, Sinoszechuanaspis yanmenpaensis (f) and Asiaspis expansa (g), reconstructions based on Pan et al. (1975, fig. 5) and Pan (1992, fig. 29). Reconstructions and images not to scale. Abbreviation: $\mathrm{mdo}=$ median dorsal opening

the temporal-spatial distribution of some stem-tetrapods is summarised in Fig. 8.

\section{Biogeographically significant Devonian vertebrate groups of East Gondwana}

\subsection{Agnathans: pituriaspids}

Three major groups of jawless vertebrates are highly diverse and widespread in Siluro-Devonian continental deposits of other regions, but unknown in Gondwana (e.g. Young 1981, 1990, 1993, 2003). Heterostracans (over 120 genera) and osteostracans (over 60 genera) are distributed across Laurussia, Siberia, and Tuva. The galeaspid agnathans (at least 50 genera), first formally described by Liu (1965), occur only in Asia. The total absence from East Gondwana of Devonian heterostracans and osteostracans, common in the Siluro-Devonian of Laurussia, indicates some sort of significant barrier or isolating mechanism. If this was an oceanic barrier it must have been of considerable extent, perhaps 750 $1000 \mathrm{~km}$ wide. It would need to have been comparable to or wider than the Uralian seaway (see Young 2003, p. 177), because in Laurussia there are many armoured agnathan occurrences in shallow marine deposits.

In contrast, only two Devonian armoured agnathans are known from Gondwana (Pituriaspis and Neeyambaspis; Young 1991). Both come from the Wuttagoonaspis assemblage in the Georgina Basin of central Australia (Young and Goujet 2003), and show a distinctive morphology, with long rostral processes (Fig. 2). They are poorly known from only a small number of specimens preserved as impressions in sandstone. Pituriaspids have been interpreted as endemic at high taxonomic level (in their own Class Pituriaspida), with a possible close relationship to osteostracans and stem gnathostomes 


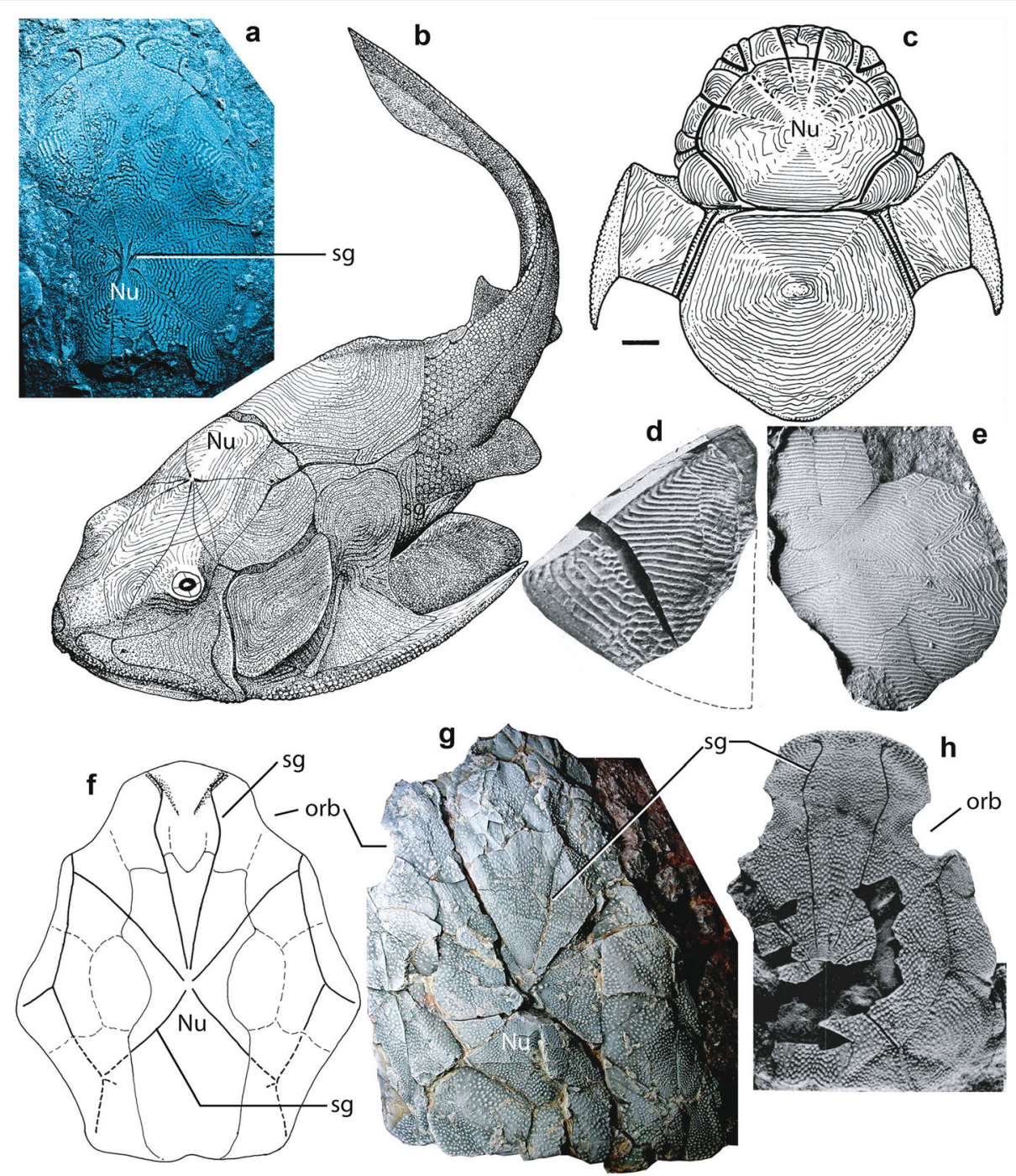

Fig. 3 Various placoderms from East Gondwana (a-g) compared with one from South China (h). a and $\mathbf{b}$ Wuttagoonaspis milligani skull (a) and reconstruction (b) as described by Young and Goujet (2003) from the Georgina Basin; c-e Phyllolepid placoderms: Placolepis dorsal reconstruction (c) after Long 1993), isolated phyllolepid bones from Victoria (d) and Antarctica (e), all showing characteristic sinuous ridged ornament; $\mathbf{f}$ Skull reconstruction of Toombalepis tuberculata described by Young and Goujet (2003); $\mathbf{g}$ Holotype skull of Edgellaspis gorteri described by Hunt and Young (2011) from the Hatchery Creek Group at Wee Jasper (locality 5, Fig. 1). h Holotype skull of Yujiangolepis liujingenesis described by Wang et al. (1998) from the Pragian of Guangxi. Images not to scale. Abbreviations: Nu= nuchal plate, orb= orbit (eye socket), sg= sensory grooves

(Young 1991; Janvier 1996, pp. 122-123). This would imply derivation from an unknown, presumably preDevonian widespread agnathan ancestor (note that Ordovician agnathans are mainly known from marine beds). However, there is a striking superficial resemblance to some South Chinese galeaspid agnathans with long rostral processes (Huananaspidiformes), such as Asiaspis or Sinoszechuanaspis (Fig. 2f-g). In addition, Neeyambaspis (known from a single skull impression, but clearly different from Pituriaspis) partly preserves a galeaspid-like median dorsal (nasohypophysial) opening (Fig. 2b-c).
Galeaspid agnathans first appeared in the Early Silurian of Asia, and became highly diverse in Asia from the Early Devonian. In South China, the Huananaspidiformes with pronounced rostral processes first appear in the Xitun fauna of Pragian age (Zhao and Zhu 2010; vertebrate assemblage III of Zhu et al. 2000), and older representatives (Sanqiaspis; Lochkovian) are recorded from northern Vietnam (Janvier et al. 2009), whereas the pituriaspids of central Australia are somewhat younger (Emsian-Eifelian). Assuming the striking resemblance to huananaspid galeaspids is valid, the appearance of pituriaspids in East Gondwana can be attributed to range 


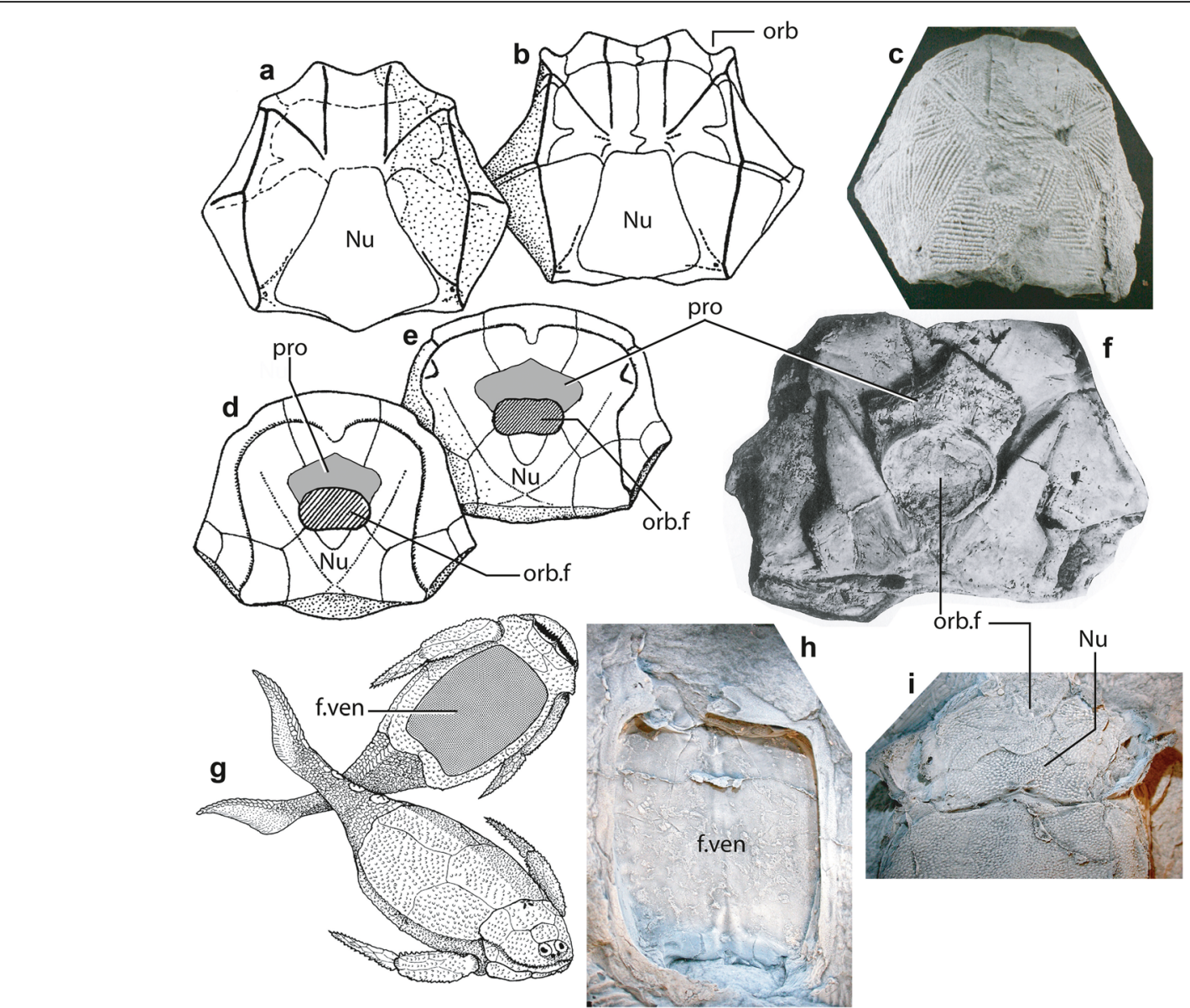

Fig. 4 Placoderm fishes suggesting shallow marine (a-c), possibly marginal marine (d and $\mathbf{f}$ ), or continental (g-i) faunal exchange between east Gondwana and east Asia. a Skull of the arthrodire Kweichowlepis from the early Emsian Duyun Assemblage of South China (after P'an et al. 1975, pl. 9, 10, fig. 1) re-interpreted as a buchanosteid; b Skull of the Australian Emsian arthrodire Buchanosteus (after Young 1979); c Buchanosteid skull (cf. Errolosteus) with ridged ornament (Wee Jasper, NSW; locality 5, Fig. 1); d and f, Skulls of the bothriolepid antiarch Bothriolepis with a pentagonal preorbital recess; d, Bothriolepis shaokuanensis (Eifelian, Guangdong, China; modified from Chang 1963 and Liu 1973); e B. karawaka, and $\mathbf{f}$ B. portalensis from the Aztec sequence (Middle-Late Devonian), southern Victoria Land, Antarctica (from Young 1988); g-i Australian sinolepid antiarch Grenfellaspis branagani (Upper Devonian, Lachlan Fold Belt; locality 9, Fig. 1); g Reconstruction based on the only known articulated specimen (from Young 1999); $\mathbf{h}$ and $\mathbf{i}$ Articulated specimen in ventral view (h, showing the unique ventral fenestra) and dorsal view (i, skull only). Images not to scale. Abbreviations: $f \cdot v e n=$ ventral fenestra, $\mathrm{Nu}=$ nuchal plate, orb= orbit (eye socket), orb.f= central opening for eyes, pro= preorbital recess

enlargement ('dispersal') from China during the faunal exchange of the E'Em bio-event (Pragian-Emsian boundary), identified by Zhu et al. (2000) as the first faunal exchange between China and Australia (event $\mathrm{A}_{1}$, Fig. 5).

\subsection{Placoderms: wuttagoonaspids, phyllolepids}

Wuttagoonaspis gave its name to the East Gondwana Province first proposed by Young (1981), based on the diverse placoderm assemblage in sandstones of the Mulga Downs Group (Darling Basin, localities 12, 13, 41, Fig. 1), named after the highly distinctive endemic genus described by Ritchie (1973). However, apart from groenlandaspid arthrodires (Ritchie 2004), much of this assemblage remains undescribed. Presumably it had comparable diversity to that documented from the Dulcie Sandstone and Cravens Peak Beds of the Georgina Basin (Young and Goujet 2003). Including the pituriaspids discussed in the previous section, the Georgina Basin Wuttagoonaspis assemblage comprises at least 16 genera in 11 families, placed in at least six orders and four classes (Agnatha, Acanthodii, Placodermi, Osteichthyes). There is a second (larger) species of Wuttagoonaspis (W. milligani; Fig. 3ab), and a diversity of arthrodires with seven new genera erected. Biogeographically, these form two groups: i) probably more primitive arthrodires (antarctaspids) that show Chinese affinities (see next section), and ii) genera referred to more widely distributed actinolepid, phlyctaeniid and groenlandaspid arthrodire families, that have long been recorded from Laurussia (e.g. central Europe, western USA, Spitsbergen, Severnaya Zemlya). 


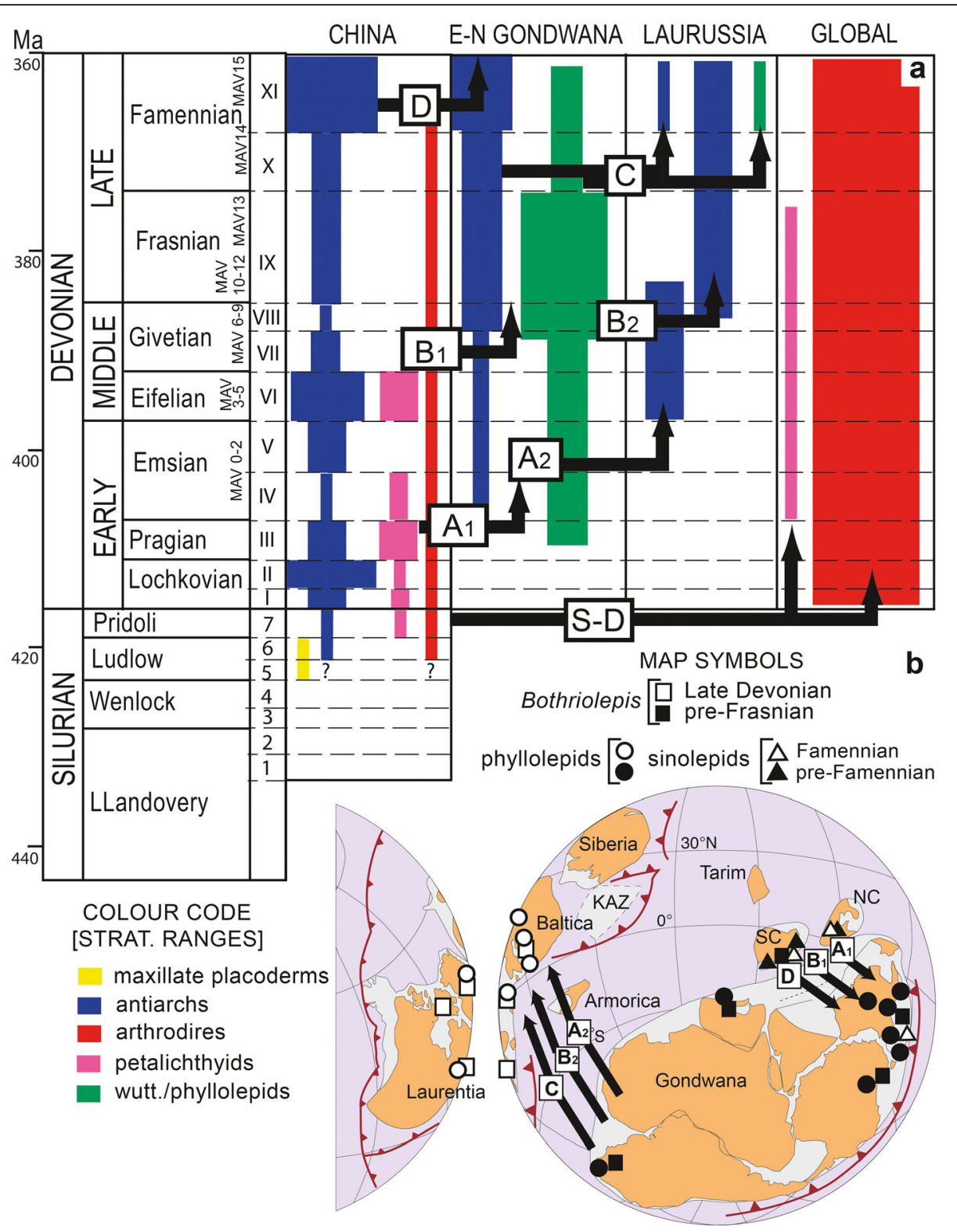

Fig. 5 a Global biostratigraphic summary for placoderms discussed in the text, showing disparate stratigraphic ranges between China, Gondwana and Laurussia, and five postulated biotic dispersal/range enlargement episodes (A-D, square boxes) to explain them. Left column shows international subdivisions for the Silurian and Devonian, with macrovertebrate assemblages MAV1-15 for East Gondwana (from Young and Turner 2000), and I-XI for China (from Zhu et al. 2000). Calibration points (Ma) from ICS International Stratigraphic Chart. Range enlargement events are: S-D, Siluro-Devonian global expansion for various gnathostome groups; $A_{1}$, Pragian-Emsian E'Em or mid-Emsian M'Em bio-events (Zhu 2000) for faunal exchange from Asia to East Gondwana, with possible later (Eifelian) extension of asterolepid antiarchs into Laurussia $\left[\mathrm{A}_{2}\right]$; $\mathrm{B}_{1}$, range enlargement into East Gondwana of Bothriolepis, from its earliest occurrence (Emsian, South China), with extension $\left[B_{2}\right]$ into Laurussia possibly

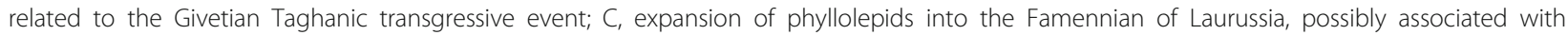
Kellwasser and Condroz Event sea level changes; other groups with similar patterns consistent with a biotic dispersal event ('Great Devonian Interchange') are groenlandaspids, rhizodontids, gyracanthids, and tetrapods; D, range enlargement of sinolepid antiarchs from South and North China into East Gondwana, possibly associated with Hangenberg Event sea level changes; $\mathbf{b}$ Summary of placoderm distributions and dispersal episodes in a on a Devonian palaeomagnetic reconstruction (Li and Powell 2001). For placoderm locality details see Young (2003, fig. 1). Abbreviations: $\mathrm{KAZ}=$ Kazakhstan, NC= North China, SC= South China. Updated from Young (2010a)

The age range of the Wuttagoonaspis assemblage has been unclear due to the dearth of marine fossils providing external age control, and the fact that many localities are in isolated sandstone outcrops with no stratigraphic context. A post-Pragian to Eifelian age range was suggested for the Cravens Peak Beds by Young and Goujet (2003), probably partly overlapping but perhaps younger than the type area in the Mulga Downs Group of 


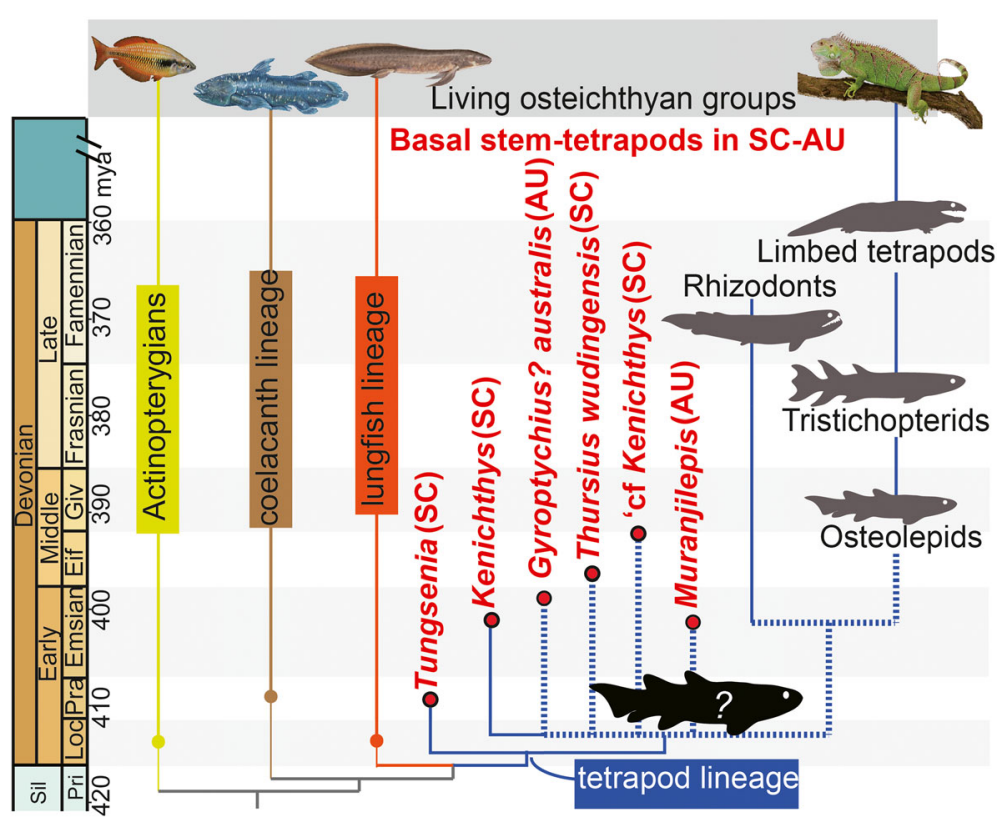

Fig. 6 Generalised phylogeny showing current ideas of relationships of the tetrapod lineage (modified from Lu et al. 2012). Basal stem-tetrapods only known from South China and East Gondwana are shown in red. Abbreviations: $\mathrm{AU}=$ Australia, $\mathrm{SC}=$ South China

western New South Wales (to explain the different Wuttagoonaspis species). An extension higher into the Middle Devonian (?Givetian) for some sites is supported by similarities in groenlandaspid arthrodire remains from the Antarctic Aztec sequence (Young and Long 2014).

Across eastern and central Australia, younger (Late Devonian) strata in these non-marine sequences are characterised by a Bothriolepis-phyllolepid fish assemblage. Phyllolepid placoderms (Fig. 3c-e) are the second group used by Young (1981) to define the East Gondwana Province. The documented range of phyllolepids in Gondwana is Emsian-Famennian, with their greatest diversity in the Givetian-Frasnian (Fig. 5), yet very rare in lowest and highest horizons (evidently small species as an insignificant part of these fish assemblages). In the youngest Australian horizons with placoderm bones (e.g. latest Famennian assemblage with the giant sarcopterygian Edenopteron keithcrooki; Young 2007; Young et al. 2013) phyllolepid plates have not been found. They are shown disappearing just before the D-C boundary (Fig. 5, E-N Gondwana column).

As discussed by Young (2005c), phyllolepid placoderms demonstrate the greatest time/space disjunction of any group of Devonian vertebrates. Agassiz (1844) erected the genus Phyllolepis for a highly distinctive isolated bone with sinuous ridged ornament from the 'Old Red Sandstone' of Scotland. Subsequently, 170 years of European research produced nine species within this one genus, all in Famennian strata of Laurussia. In contrast, three decades of research on the phyllolepids of
East Gondwana (Long 1984; Ritchie 1984, 2005; Young 2005a, b, c; Young and Long 2005) documented five genera: Austrophyllolepis, Placolepis, Cobandrahlepis, Yurammia, and Cowralepis. The first four are represented by several species in eastern Australia and Antarctica. On the Australian craton, different species of Austrophyllolepis and Placolepis have been recorded in the Georgina and Amadeus basins (localities 21, 23, Fig. 1). The first Gondwanan appearance of phyllolepids sensu stricto (Emsian) is based on the oldest Placolepis (and phyllolepid) in the Jauf Formation of Saudi Arabia ('Placolepis n. sp.'; Lelièvre et al. 1999, fig. 3C). Thus, a Gondwanan origin for the group is strongly indicated, supported by a close relationship to Wuttagoonaspis as proposed by many authors (e.g. Miles 1971; Young 1980; Long 1984; Young and Goujet 2003). In contrast, possible precursors of both Wuttagoonaspis and phyllolepids have been suggested from the Early Devonian of China (Dupret 2008; Dupret and Zhu 2008), but based only on single incomplete skulls, neither of which shows the distinctive and characteristic ridged ornament of wuttagoonaspids and phyllolepids (Fig. 3a-c). Ridged ornament remains are more likely to be observed by field geologists, even as fragmentary bones (Fig. 3d-e). These are a very common component in all Devonian fish assemblages of East Gondwana, but neither wuttagoonaspids nor phyllolepids are known from the diverse younger Devonian fish assemblages in Asia. A new phylogenetic analysis (Hunt and Young 2011) failed to recover the sister group relationship between Wuttagoonaspis (Australia) 


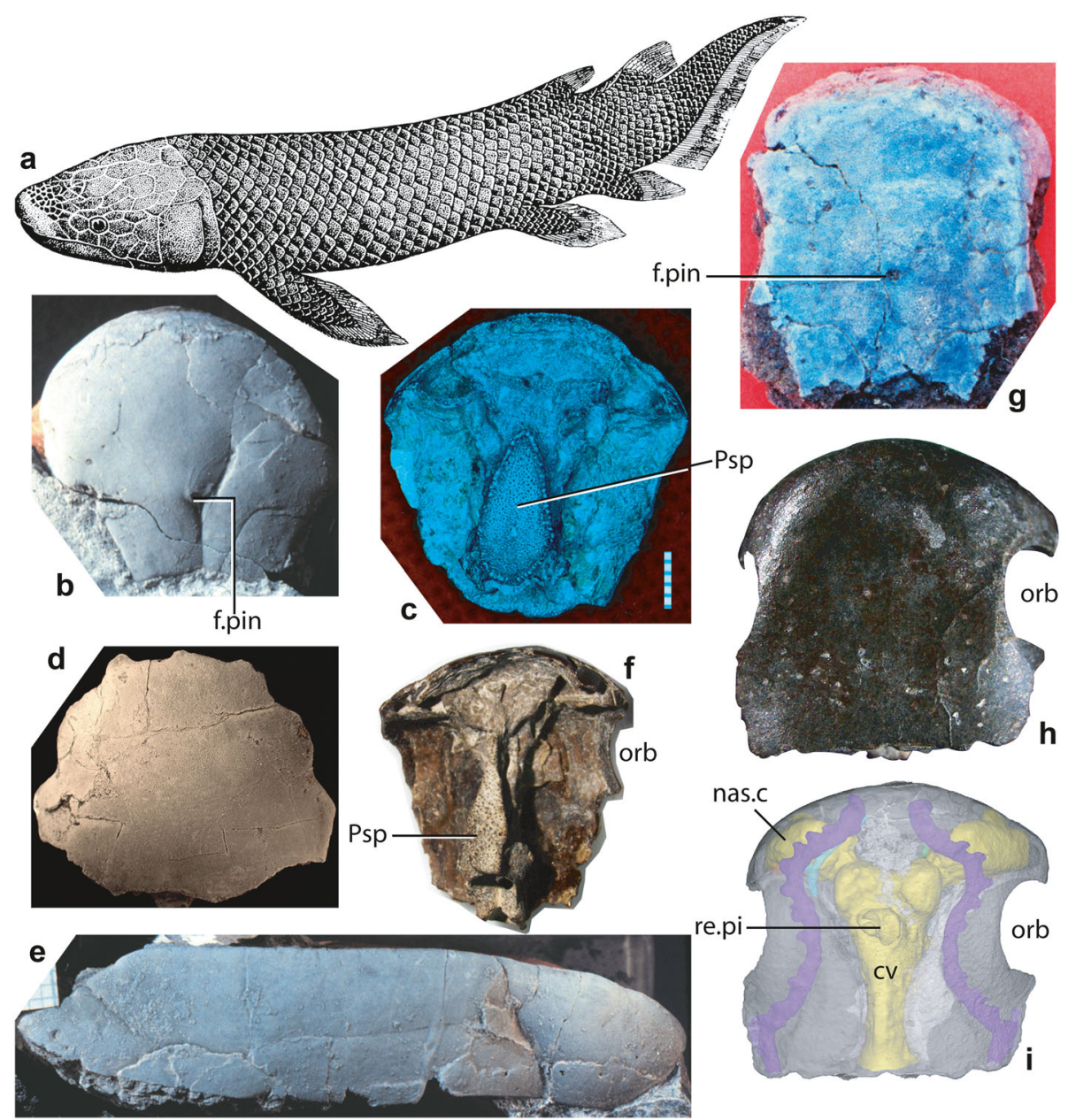

Fig. 7 Osteichthyan fishes suggesting shallow marine (a), or marginal marine/continental (b-i) faunal exchange between East Gondwana and South China. a Restoration (by R.E. Barwick) of the Early Devonian lungfish Speonesydrion from Burrinjuck (locality 5, Fig. 1); b-e cf. Kenichthys (previously 'Gyroptychius? australis) from Hatchery Creek; parietal (b and c, dorsal and ventral) and post-parietal (d, dorsal) skull shields, and right lower jaw (e, external view); f Kenichthys from South China, parietal shield in ventral view; $\mathbf{g}$ Muranjilepis from central Australia, parietal shield, dorsal view; $\mathbf{h}$ and $\mathbf{i}$ Tungsenia (South China) parietal shield, dorsal view (h) and CT scan image showing brain cavity (i). a-e from locality 5 ,

$\mathbf{g}$ from locality 24 (Fig. 1); $\mathbf{f}, \mathbf{h}$ and $\mathbf{i}$ from Yunnan Province, in the Pragian of Zhaotong (Tungsenia) and Emsian of Qujing (Kenichthys). Images not to scale. Abbreviations: $\mathrm{cv}=$ brain cavity, f.pin= pineal opening, nas.c= nasal capsule, orb= orbit (eye socket), Psp= parasphenoid bone in palate, re.pin= recess for pineal and para-pineal organs

and Yiminaspis (China) proposed by Dupret (2008), the resemblances residing mainly in primitive arthrodire skull characters (discussed further in the next section).

\subsection{Placoderms: arthrodires}

As noted above, the diverse arthrodires documented from the Wuttagoonaspis assemblage of the Georgina Basin by Young and Goujet (2003) included some evidently more primitive forms suggesting Chinese affinities (Fig. 3f-h). Toombalepis from the Cravens Peak Beds (Fig. 3f) was assigned to the actinolepid family Antarctaspididae, other members being Antarctaspis (Antarctica) and Yujiangolepis (South China; Fig. 3h). All of these share a large nuchal plate in the centre of the skull that carried converging sensory grooves. However, this is a general resemblance residing mainly in primitive arthrodire skull characters, being also seen in many other groups, including wuttagoonaspids and phyllolepids (Fig. 3a-c), and petalichthyids (e.g. Eurycaraspis from China). Some Laurussian actinolepid arthrodires (e.g. Aethaspis) have a similarly elongate nuchal plate (Hunt and Young 2011, fig. 7). The incomplete skull of the Chinese 'wuttagoonaspid' Yiminaspis Dupret (2008) preserves the same general feature (other supposed resemblances to Wuttagoonaspis are mainly non-preserved and shown as dashed lines). A large nuchal plate with converging sensory grooves is displayed in the skull of Edgellaspis from the Hatchery Creek Group (Fig. 3g).

The Hatchery Creek Group is an alluvial fan deposit with abundant fish and plant remains (Hunt and Young 


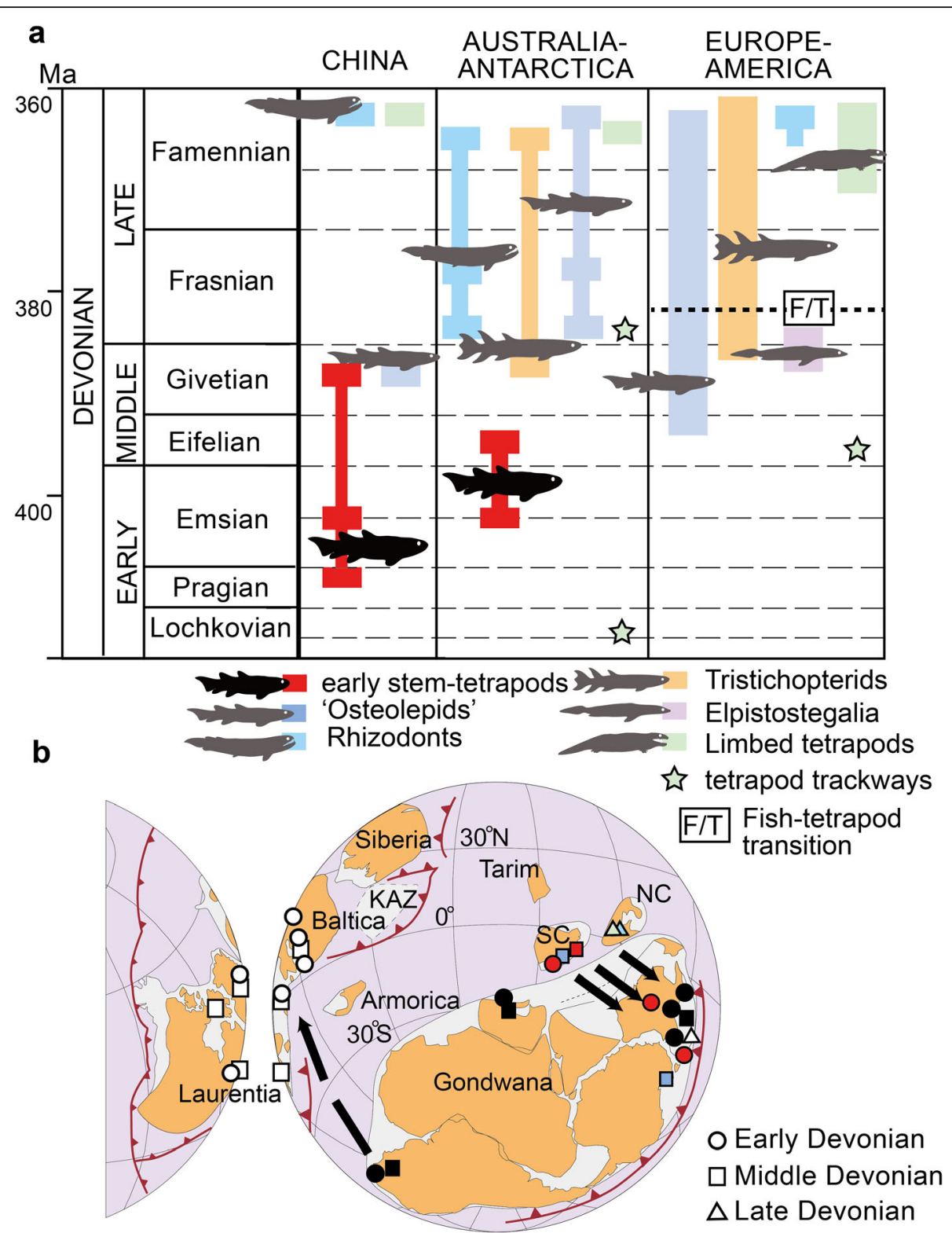

Fig. 8 a Disparate stratigraphic ranges for some major stem-tetrapod fish groups between Asia, Gondwana, and Laurussia (Europe-America); b Summary of relevant stem-tetrapod distributions and possible dispersal episodes on a Devonian palaeomagnetic reconstruction (Li and Powell 2001; for fossil locality details see Young 2003, fig. 1)

2012), about $1800 \mathrm{~m}$ thick and conformably overlying the Emsian marine limestones at Wee Jasper (locality 5, Fig. 1). The fauna includes early tetrapodomorphs indicating Chinese affinity as discussed below. The parallelsided skull of Edgellaspis is another highly unusual feature seen in placoderm outgroups (Hunt and Young 2011), whilst the tubercular ornament shows a strong tendency to alignment, as in some primitive phyllolepids (e.g. Young et al. 2010, fig. 4d). These early arthrodires from China, Australia and Antarctica show a range of primitive characteristics never seen in the much better studied arthrodire faunas of Laurussia, and thus are interpreted to have had limited dispersal capacity. They can be explained by palaeogeographic connections resulting in faunal exchange related to the E'Em bioevent approximating the Pragian-Emsian boundary (Zhu 2000).

A more widespread arthrodire group are the buchanosteids, which are diverse in the Burrinjuck marine limestones underlying the Hatchery Creek Group just discussed (locality 5, Fig. 1). The type area is Buchan, Victoria (locality 2, Fig. 1), which produced the original specimen named Buchanosteus (Hills 1936; Stensiö 1945) from equivalent limestones of Emsian age. The 
buchanosteids are primitive brachythoracids characterised by a rostral capsule separate from the rest of the skull and braincase (Fig. 4a-c), a feature never recorded in the brachythoracids of Laurussia. The most diverse assemblage is from Burrinjuck (genera Parabuchanosteus, Errolosteus and Richardosteus; Long et al. 2014). Young and Janvier (1999) first noted that a Chinese Emsian arthrodire skull Kweichowlepis (Fig. 4a) shows close resemblance to Buchanosteus from Australia (Fig. 4b). Wang (2005) summarised the range of Buchanosteus in China, extending down to the early Lochkovian (Yulin, Guangxi Zhuang Autonomous Region; Zhao and Zhu 2010). Again, an 'out-of-China' origin at the Pragian-Emsian boundary as part of the E'Em bio-event (Zhu 2000) can be suggested, perhaps related to marine transgressions in the early Emsian documented for both South China (Ma et al. 2009) and eastern Australia (Young 1996; Mawson and Talent 2003). These shallow marine fishes were widespread along the northern Gondwana margin, up the Uralian seaway (Uralosteus; Mark-Kurik and Young 2003), and in Severnay Zemlya (Urvaspis; Long et al. 2014). As biogeographic/palaeogeographic indicators with different marine tolerance, they show quite different distribution patterns compared to the primitive non-brachythoracid arthrodires (Edgellaspis, Toombalepis, Yujiangolepis) just discussed.

\subsection{Placoderms: antiarchs}

The yunnanolepid antiarchs, together with galeaspid agnathans, gave the name for the Yunnanolepid/Galeaspid Province of Young (1981), which was renamed the 'Pan-Cathaysian Galeaspid Province' by Zhao and Zhu (2010). The diversification of these groups in the Silurian-Early Devonian of China (e.g. Zhao and Zhu 2007) represents one of the most dramatic endemic radiations in vertebrate evolutionary history. Of over 40 antiarch genera recognised in the most recent phylogenetic analysis, eight genera are yunnanolepids (Wang and Zhu 2018). This highly endemic group is only known from Asia. First formally documented from Yunnan Province of South China by Liu (1963), fragmentary remains had much earlier been collected from northern Vietnam by Mansuy (1915). Many new localities in this area (e.g. Racheboeuf et al. 2005) lie north of the Song Ma suture (see Wang et al. 2010a, fig. 1), and thus represent an extension of the South China Block. The discovery of yunnanolepid remains in Vietnam south of the Song Ma suture, on the 'Indochina terrane' (Tong-Dzuy et al. 1996), provided the first clear evidence of close faunal (and therefore palaeogeographic) connection with the highly endemic yunnanolepid-galeaspid fossil fish of the South China Block.

At the other extreme is the antiarch Bothriolepis (Fig. 4d-f), the most widespread Devonian fish. It is known from all regions of the world preserving Upper Devonian strata, with over 60 species recognised world-wide. Traditionally, Bothriolepis was typical of non-marine 'Old Red Sandstone' deposits, from which it was first described (Famennian of Russia; Eichwald 1840). Subsequently a small number of occurrences have been demonstrated in calcareous beds associated with marine invertebrates, indicating that these species at least had a tolerance of salt-water. Such a widespread form therefore seemed unlikely to contribute much to considerations of biogeography and palaeogeography.

In the Southern Hemisphere, Bothriolepis was first identified from the Aztec sequence of Antarctica by Woodward (1921), and considered sufficient to demonstrate a Late Devonian age based on occurrences in Europe and North America. Exhaustive studies of the species B. canadensis by Stensiö (1948) seemingly left little to be discovered regarding morphology. However, in a detailed study of very extensive Antarctic material, Young (1988) identified a new type of preorbital recess of the skull in three Antarctic species (B. portalensis, $B$. karawaka, B. macphersoni; Fig. 4e-f). Remarkably, this structure was otherwise only known in two Chinese species: B. shaokuanensis (Fig. 4d) and B. niushoushanensis. Both are of middle Eifelian age, in the Tiaomajian Assemblage of South China and the Shixiagou Assemblage of Ningxia (North China Block; Zhao and Zhu 2010). This indicates faunal exchange between these regions in the Middle Devonian for this species group, to the exclusion of other areas. Another significant aspect relative to palaeogeography was a demonstrated temporal discordance in China compared to the Late Devonian age assumed by European researchers, first noted by Wang (1943), but dismissed for decades. Bothriolepis is first recorded in the late Emsian Chuandong Assemblage of Yunnan Province (Zhao and Zhu 2010), whereas its European first occurrence (late Givetian of the Baltic region) indicates a range enlargement episode from ChinaGondwana near the Middle-Late Devonian boundary ( $\mathrm{B}_{2}$, Fig. 5).

The Asterolepiformes is the second major European grouping of antiarchs, based on Asterolepis Eichwald (1840) from the Frasnian of the Baltic. Previous evidence suggested the group was absent from the Early Devonian of Asia, with the later appearance of endemic Middle Devonian (e.g. Hunanolepis), and cosmopolitan Upper Devonian forms (Remigolepis; Pan et al. 1987). Note that 'Asterolepis' sinensis Pan (1964), based on material from the Wutung Group near Nanjing, was shown by Zhang and Liu (1991) to be congeneric with Jiangxilepis, a bothriolepid antiarch. Recently, Pan et al. (2017) suggested that Luquanolepis (Emsian, Yunnan Province) could belong in this group (previously interpreted as a 
probable bothriolepid; Zhang and Young 1992). However the skull of Luquanolepis is not known, so this result is very provisional (and not supported in the analysis of Wang and Zhu 2018). Asterolepid affinity is anomalous given that all other Chinese antiarchs (except Hunanolepis, Remigolepis) are yunnanolepids, bothriolepids, or sinolepids. Janvier et al. (2003) suggested some ornamented fragments from Tra Ban Island, Vietnam, could also indicate an asterolepid antiarch, but such tuberculate ornament is seen in a majority of placoderm groups, so better evidence is needed.

Currently there is no clear indication of asterolepids in the Early Devonian of Asia. In contrast, the Early Devonian of Gondwana has produced acid-prepared remains of an unnamed asterolepid (Young 1984) from the Cravens Peak Beds limestone of the Georgina Basin (locality 20, Fig. 1). Its probable Emsian age, based on the presence of an ostracod very close to Healdianella subdistincta described from the Emsian Sipai Formation (Guangxi) by Wang (1983), indicates this is probably the oldest confirmed occurrence of the asterolepid antiarchs in the fossil record. The slightly younger (Emsian-Eifelian) asterolepid Sherbonaspis comes from the Hatchery Creek fish assemblage at Wee Jasper, associated with the primitive arthrodire Edgellaspis (discussed above), and basal tetrapodomorphs close to the Chinese Kenichthys (see next section). In summary, these data suggest that asterolepiform antiarchs were present in East Gondwana as early as, or earlier than, in Laurussia, even if the typical Middle Devonian radiation of species of Asterolepis is not evident.

The antiarch family Sinolepididae (Liu and Pan 1958), as the name suggests, is a distinctive Asian taxon showing clear distributional evidence for Chinese origins. Sinolepids have a highly unusual morphology with a large rectangular opening or fenestra in the ventral trunk-armour (Fig. 4g-h), a structure unknown in any other placoderm group. The genotype of the family (Sinolepis) has its type area in the Wutung Group near Nanjing (Famennian Leigutai Assemblage of Zhao and Zhu 2010). Other sinolepids (Liujiangolepis, Dayoshania, Xichonolepis) range right through the Devonian of China, and possibly in the Early Devonian of northern Vietnam (?Vanchienolepis). A Late Devonian range enlargement into Gondwana (event 'D', Fig. 5) was demonstrated by the discovery of the genus Grenfellaspis Ritchie et al. (1992) in the Lachlan Fold Belt of eastern Australia (locality 9, Fig. 1). The late Famennian age of the Grenfellaspis assemblage of East Gondwana was confirmed with the discovery of a single articulated specimen (Fig. 4h-i) high in the Hervey Group sequence of central NSW (Young 1999). Sinolepids have also been found at other localities in the late Famennian of central NSW (e.g. Bumberry syncline; Young et al. 2010, fig. 8F-G).
Other fossil groups support a faunal connection across the Devonian-Carboniferous boundary (e.g. Ritchie et al. 1992; Webb 2000).

\subsection{Osteichthyans: dipnoans}

The diverse Early Devonian lungfish fauna of southeastern Australia (Fig. 7a) has been documented in numerous publications. From the Pragian-Emsian limestone sequence of Burrinjuck, five species are assigned to four genera (Dipnorhynchus, Speonesydrion, Cathlorhynchus, Placorhynchus; see Campbell et al. 2009). Wang et al. (1993) had already described Sorbitorhynchus from the Emsian of Guangxi Zhuang Autonomous Region, noting the close affinity with Dipnorhynchus from Burrinjuck. From the Pojiao Formation (early Emsian) of Wenshan, Yunnan Province, Chang and Wang (1995) described the dipnoan Erika jarviki (Dipnorhynchidae). Recently Qiao and Zhu (2015) recorded from Guangxi Zhuang Autonomous Region a new species of the Burrinjuck genus Cathlorhynchus. Qiao and Zhu (2015) noted a widespread ('trans-Panthalassic') Early Devonian distribution for the Dipnorhynchus lineage. As discussed above for the arthrodire Buchanosteus, this would be expected for shallow marine tropical environments. However, the more closely related taxa (species) between China and Australia may be considered an indicator of geographic proximity. Again, given the slightly older age of the Chinese occurrences, faunal exchange related to the E'Em bio-event of Zhu et al. (2000) can be proposed.

\subsection{Osteichthyans: tetrapodomorphs}

The origin of land animals from fishes was one of the major events in vertebrate evolutionary history, which has fascinated scientists and the general public since before the time of Charles Darwin (e.g. Lu et al. 2016). Where and when the first tetrapods (land vertebrates) evolved is still shrouded in uncertainty. However, the traditional morphological gap between fishes and amphibians has been partly closed by a wealth of fish-like fossil 'stem-tetrapods', many discovered since the mid 1980s. These represent the more advanced part of the stem-tetrapod lineage, and mainly come from the Laurussian palaeocontinent (Europe or North America).

Over the last 15 years, various extinct lobe-finned fishes (sarcopterygians) have been discovered in the remarkable fossil fish assemblages of South China, some of which represent the basal part of the tetrapod stemlineage (Fig. 6, in red). The oldest and basal-most stemtetrapod so far known is Tungsenia Lu et al. (2012) from the Pragian ( $\mathrm{Lu}$ and Zhu 2008), and the next most basal is the Emsian Kenichthys Chang and Zhu (1993). Both come from South China (Fig. 6), and examples are illustrated in Fig. 7f, h-i. Close resemblances between Kenichthys and Australian material from the Hatchery 
Creek Group (locality 5, Fig. 1) was noted over 20 years ago by Chang and $\mathrm{Yu}$ (1997). Initially this material (Fig. 7b-e) was provisionally referred to the Laurussian genus Gyroptychius (Young and Gorter 1981), but most recently several closely related forms are recognized including one listed as cf. Kenichthys (Hunt and Young 2012). Another closely related stem-tetrapod is Muranjilepis (Fig. 7g) described by Young and Schultze (2005) from the Amadeus Basin of central Australia (locality 24, Fig. 1). The detailed relationship between these Australian forms and other Chinese basal stem-tetrapods (e.g. from Wuding, referred to the Laurussian taxon Thursius) is ongoing research by the authors. All these taxa (names in red in Fig. 6) are strong indicators of faunal exchange between South China and East Gondwana in the Early Devonian.

Figure 8 summarises the Devonian time-space distribution for major tetrapodomorph groups and related sarcopterygians. Until a decade ago it was argued that overwhelming fossil evidence showed the 'fish-tetrapod transition' (F/T, Fig. 8a) had occurred on the Laurussian palaeocontinent during a 10 million-year time interval of the Late Devonian ( 372-382 Ma; Ahlberg and Clack 2006; Clack 2007; cf. Young 2006). Then a discovery in Poland of much older possible vertebrate trackways and footprints (Niedźwiedzki et al. 2010) implied that animals with limbs had already evolved before the Middle Devonian. Similar trackways from Australia (Warren et al. 1986) had previously been dismissed as too old, because of a long gap before the first occurrence of tetrapod body fossils (rare examples in the Upper Devonian of Laurussia and Australia). The older Australian and Polish trackway evidence is controversial (e.g. Lucas 2015; cf. Friedman and Brazeau 2011). However, other Middle Devonian trackways still imply that previous assumptions about the fish-tetrapod transition occurring in the Late Devonian is an artefact of an incomplete fossil record from one palaeocontinent (Laurussia). The new trackway evidence focussed attention on regions of the world less investigated than Europe and North America, such as Asia and Gondwana. Gondwana was the largest landmass of the Devonian, but its fossil record remains poorly known.

In Laurussia, tetrapodomorph fishes only occur in strata of Middle Devonian age or younger (Fig. 8a). The oldest tristichopterids (e.g. Tristichopterus from Scotland, Eusthenopteron from Canada) occur near the Middle-Late Devonian boundary (previously considered good supporting evidence for Late Devonian tetrapod origins in Laurussia). The Pragian-Eifelian age range now established for the genera Kenichthys, Tungsenia, 'Thursius', and related forms from South China, and 'Gyroptychius', cf. Kenichthys and Muranjilepis from
Australia (Fig. 6), makes them older than any tetrapodomorphs from Laurussia. Thus, earlier interpretations that they were 'migrants' from a European evolutionary centre are no longer tenable. The older age and basal phylogenetic position indicates instead dispersal or range enlargement to Europe, the most direct route on palaeogeographic reconstructions being along the northern Gondwana margin ('South Route' of Zhao and Zhu 2010, fig. 6B).

Similarly, tristichopterids were considered of northern origin, with Australian and Antarctic representatives interpreted as more derived, having dispersed from the north into East Gondwana (Ahlberg and Johanson 1997; Johanson and Ahlberg 2001). The underlying assumption is that basal taxa, or stratigraphically older taxa, or both, indicate the centre of origin for the group concerned (Young 2010b; Young et al. 2010). However, alternative interpretations, of endemic tetrapodomorph subgroups (e.g. Canowindridae, Mandageriinae) in Australia-Antarctica (Young 2008; Young et al. 1992, 2013, 2019) are consistent with the placement of the only Australian taxon (Marsdenichthys) in the analysis of Lu et al. (2012, fig. 6), resolved as the sister-group to all other tristichopterids.

Nevertheless, given the diverse basal tetrapodomorphs in the Lower Devonian of China, it is surprising that tristichopterids have not been found in the Frasnian (Fig. 8a, left column), at a time when they are most diverse in both East Gondwana and Laurussia. This seems only explicable by palaeogeographic change. One possibility is that increasing sea-level during the Frasnian, leading to the global maximum transgression near the Frasnian-Famennian boundary (e.g. Young 1996; Mawson and Talent 2003), may have isolated continental areas and prevented dispersal of fishes with limited marine tolerance, perhaps including tristichopterids.

\section{Discussion}

3.1 A key Devonian vertebrate site: Toomba RangeCravens Peak, Georgina Basin

The area occupied by the Wuttagoonaspis assemblage, from western NSW and across central Australia, covers about 1 million $\mathrm{km}^{2}$ of the Australian craton (Young and Goujet 2003). In the Georgina Basin of central Australia it extends from the east, in the Toko Syncline area of western Queensland, to the Dulcie Range in the Northern Territory (localities 20-21, Fig. 1). To the west it occurs in equivalent strata along the MacDonnell Ranges of the Amadeus Basin, being identified in the upper part of the Mereenie Sandstone at Mt Winter (Young and Turner 2000; Young and Schultze 2005; locality 24, Fig. 1).

This highly diverse assemblage represents the first vertebrate fauna to occupy the Australian continent (as 
opposed to marine forms in the shallow seas of the Ordovician). The containing strata represent the upper part of thick non-marine clastic sequences characterising the Early-Middle Palaeozoic of central Australia, with an age range from Ordovician to latest Devonian/Early Carboniferous. These were laid down following regression of the Early Palaeozoic 'Larapintine seaway' (which bisected the continent from east to west until the Late Ordovician). It is noted that the Palaeozoic in both the Amadeus and Georgina basins is either producing (Mereenie Oil and Gas Field) or being actively explored for hydrocarbons (see Ahmad and Munson 2013; current projects of Central Petroleum; http://centralpetroleum.com.au). In the southern Georgina Basin, Cambrian marine sediments are considered the likely source rocks (e.g. Ayling et al. 2016), and the overlying clastics (including Siluro-Devonian with fossil fish remains) as potential reservoirs.

In the 1970s a new limestone outcrop was found beneath the Devonian Cravens Peak Beds. It is very isolated (locality 20, Figs. 1 and 9a), at the southern end of the Toko Syncline and on the edge of the Simpson Desert, in an area where lack of outcrop but possible petroleum prospects had long been recognized (Sprigg 1963). The outcrop was sampled for microfossils on the assumption it would be either Cambrian or Ordovician, the typical age of marine limestones in this region. Surprisingly, it contained Devonian ostracods and thelodont agnathans (Turner et al. 1981), the first Devonian occurrence in central Australia to produce fossils indicating marine to marginal marine conditions.

Since then, a diverse fish assemblage has been documented from this limestone. In addition to the firstdiscovered thelodonts (Turner 1995, 1997), it contains asterolepid antiarchs (Young 1984), the 'notidanid' shark Mcmurdodus (Turner and Young 1987; Burrow et al. 2008), various acanthodians (Burrow and Young 2005), and osteolepid, holoptychiid, dipnoan, and onychodontid osteichthyan remains (Young and Schultze 2005). Several new groups are not yet described. Generally, the described assemblage shows little affinity to that of South China, in contrast to the associated ostracods (very close or identical to Healdianella subdistincta from the late Emsian Sipai Formation of Guangxi Zhuang Autonomous Region; Wang 1983). The thelodont Turinia is widely distributed across Gondwana, but also known from Asia (west Yunnan, part of the Shan-Thai Terrane, and also South China Block), and evidently was able to disperse in marine environments. The shark Mcmurdodus seems clearly a Gondwanan form (first described from Antarctica). Chondrichthyans generally are poorly represented in Siluro-Devonian fish faunas of South China; they have been suggested as a vertebrate equivalent of the cool-water Malvinokaffric biogeographic province for Siluro-Devonian invertebrates (e.g. Young

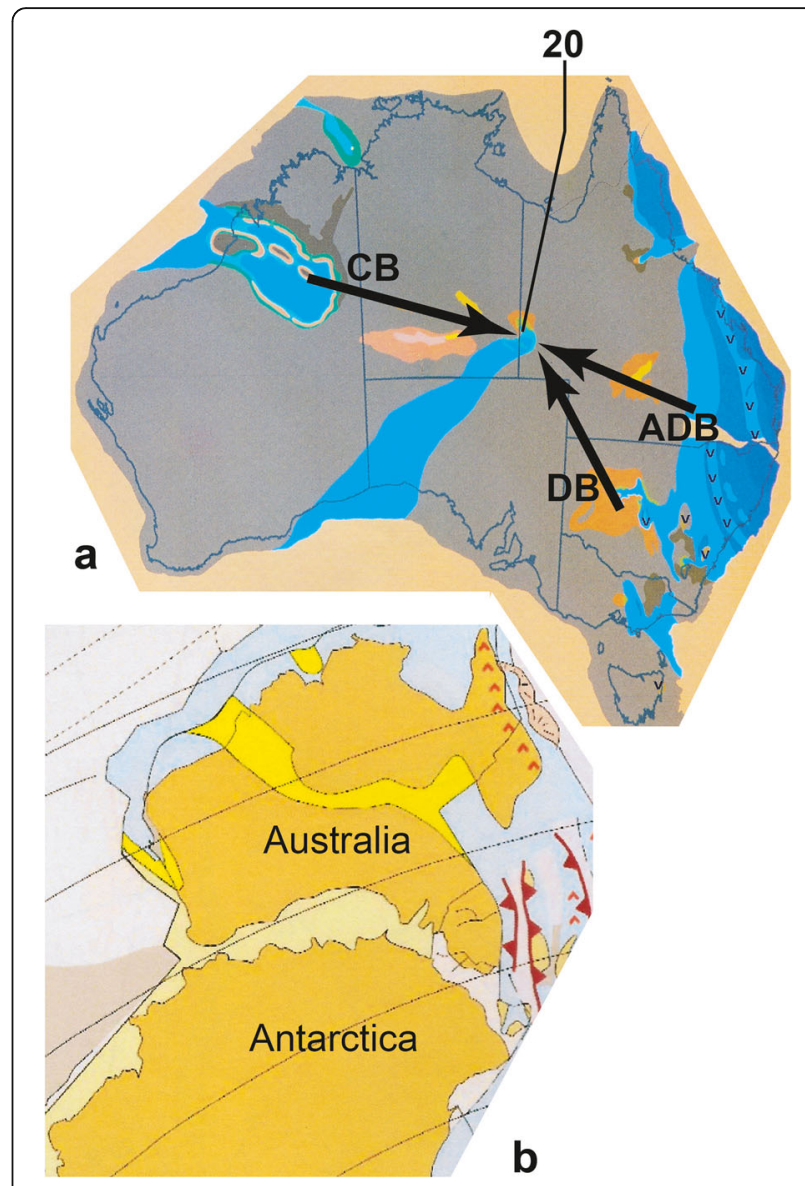

Fig. 9 a Palaeogeography for the Early Devonian of Australia (Timeslice 3' of Wilford and Olissoff 1990), showing a marine incursion from the southwest to reach the Cravens Peak limestone, Toko Syncline (locality 20, Fig. 1). Alternative marine incursions (arrows) from the Canning, Adavale and Darling basins (CB, ADB, DB) are discussed in the text; $\mathbf{b}$ Early Devonian palaeogeographic reconstruction for East Gondwana (Australia attached to Antarctica) after Li and Powell (2001, fig. 12b)

1995a). The only suggestion of a possible South Chinese element from the Cravens Peak limestone fish concerns unusual 'osteolepid' scales with posterior serrations described by Young and Schultze (2005), noted by Friedman and Brazeau (2010) to resemble in some respects the scales of the early osteichthyan Guiyu Zhu et al. (2009) from the Silurian (Ludlow) Kuanti Formation of Yunnan Province.

\subsection{Palaeogeographic setting and map representation}

Without the discovery of Devonian microfossils, the Cravens Peak outcrop would have been readily assigned to Cambro-Ordovician marine limestones that are widespread in this region. Based only on lithofacies, the new site would have had little palaeogeographic signficance. Biostratigraphic age control is a key contributor to palaeogeographic map reconstruction, by correlating 
relevant facies in different stratigraphic sections. With the new age assignment based on marine-marginal marine microfossils, the Cravens Peak limestone acquired new significance regarding Devonian palaeogeography for central Australia.

There has been some discussion about the validity of basing palaeogeographic maps on modern geography, or whether they should also take account of plate tectonic reconstructions, or detailed consideration of interaction of 'terranes' in mobile orogenic belts (e.g. 'orogenic palaeogeography'; Feng et al. 2012). Terranes ('geodynamic units' of Verard et al. 2015) are assumed to have had separate palaeogeographic histories, and in some regions (e.g. the geological composite of eastern Asia), it seems necessary to take them into account for palaeogeographic map compilation. For Palaeozoic Australia, the Lachlan Fold Belt in the east may have involved separate terranes (e.g. McElhinney et al. 2003). However, for the craton at least it seemed reasonable to base a series of palaeogeographic maps on modern geography, as in the Australian Government 'Palaeogeographic Maps Project' (Struckmeyer and Totterdell 1990).

However, the example of the Cravens Peak limestone reveals difficulties with that approach. To explain its palaeogeographic setting, a long marine extension from the southwest (Fig. 9a) was proposed for the relevant Early Devonian time-slice (Wilford and Olissoff 1990; Walley and Cook 1991, fig. 9). This evidently relied upon a single well producing similar thelodont fish scales in the Officer Basin (Long et al. 1988), rather than hypothetical marine extensions either from the northwest (Canning Basin) or from eastern Australia, both of these areas having thick sequences demonstrating marine Devonian (arrows, Fig. 9a). Walley and Cook (1991) gave two objections to the western connection to the Canning Basin, which was first proposed by Turner et al. (1981): drill hole data in the Canning suggested a topographic high to the east, and the Devonian in the Amadeus Basin was entirely non-marine. However, extensive limestone outcrops (mostly undated) have been noted in the western Amadeus Basin by Young and Turner (2000) and Young and Schultze (2005). To the east of the Toko syncline, Devonian marine sedimentary rocks are widespread throughout Queensland, the relevant sedimentary basins (e.g. Adavale, Drummond, Burdekin; Fig. 1) considered structural remnants of larger sedimentary provinces (McKillop 2013). Emsian-Eifelian allochthonous limestones adjacent to the Drummond Basin ('Ukalunda Shelf; Henderson et al. 2013) may extend into the subsurface Belyando Basin (Draper 2013). To the west, in the subsurface Adavale Basin (that hosts the Devonian Gilmore gas field; Randall 2013), subsurface Devonian may extend into the poorly known Warabin and Barrolka troughs (McKillop 2013), which lie about 400 $\mathrm{km}$ south-east of the Toko syncline, but with no intervening Devonian outcrop. Similarly, there is no outcrop into the north-western part of New South Wales, where an extensive but poorly dated Devonian succession occurs in the subsurface Bancannia trough (BT, Fig. 1). In outcrops of the adjacent Darling Basin, Early Devonian marine transgressions are dated as Lochkovian (woschmidti and pesavis conodont zones; Mawson and Talent 2000), but given the highly similar Devonian fish assemblages (see above) a marine connection to the Toko syncline is also possible (DB, Fig. 9a).

Using a Gondwana reconstruction with Antarctica and Australia juxtaposed (Fig. 9b) makes the southwestern Devonian marine extension proposed in Wilford and Olissoff's (1990) Early Devonian palaeogeographic map very improbable. The adjacent region of Antarctica is an igneous/metamorphic terrain, which was cratonic for most of the Palaeozoic (e.g. Boger 2011, fig. 13), so the possibility of corresponding unknown marine Devonian strata is extremely unlikely.

The reconstruction of Li and Powell (2001, fig. 12) has Australia placed on the eastern Gondwana margin between $10^{\circ} \mathrm{S}$ and $40^{\circ} \mathrm{S}$, with the North and South China blocks above the equator and off the northern Gondwana margin at similar palaeolatitudes. By the Late Devonian, the South China Block had crossed the equator to have the same southern palaeolatitude as eastern Australia. Based on Chinese Cambrian and Silurian palaeomagnetic data, and an assumed correspondence in the apparent polar wander paths for South China and Australia/East Gondwana, Yang et al. (2004) also showed South China attached to northwestern Australia. Zhao and Zhu (2010, fig. 6) show combined South China, North China and Tarim blocks in this position (their 'Pan-Cathaysian Galeapid Province'). The palaeoclimatic data maps of Boucot et al. (2013) again show all the Asian blocks and terranes attached to the northwest margin of Australia through the Silurian-Devonian time interval. Thus, given these various reconstructions, an assumed marine incursion from the Canning Basin (CB, Fig. 9a) would represent a direct connection with the Siluro-Devonian vertebrate assemblages of Asia. In contrast, an incursion from the east would be less direct (perhaps more consistent with the minimal Asian affinities on the Cravens Peak limestone fish assemblage).

However, the assumption that juxtaposition of palaeoblocks on a plate tectonic reconstruction means a palaeogeographic connection is greatly oversimplified. Sea-level fluctuations would dramatically change connections or barriers between areas (discussed below). Other problems include the difficulty of accommodating tectonic deformation, stretched continental margins, compression in highly deformed fold belts representing collision zones, and lost ocean floor sediments with 
obliteration of former oceans. All are long recognised issues preventing more realistic palaeogeographic reconstructions using palinspastic base maps (e.g. Ziegler et al. 1985). These issues indicate some of the limitations to standard map representations for palaeogeographic data. It is noted that in the most recent palaeogeographic maps based only on palaeomagnetic constraints (Huang et al. 2018), the South China Block and various south-east Asian terranes are shown closely juxtaposed to the western Australian margin in the Silurian, but drifting away to the west during the Devonian. This is completely the opposite to what is indicated by the highly endemic Devonian fish assemblages of the 'PanCathaysian landmass' of the Late Silurian-Early Devonian (Zhao and Zhu 2010).

\subsection{Alternative representations of palaeogeographic data}

The reconstruction of past geography, like most aspects of historical Earth Science, relies on a range of geological, geophysical, and biological empirical data. How disparate data sets can be integrated, to produce a coherent and testable hypothesis of changing geography through time, has remained elusive and controversial. An oversimplification of the data integration problem is to distinguish between qualitative and quantitative evidence, the latter component (primarily palaeomagnetic data) considered superior because they can be represented as numbers. The standard representation of palaeogeographic data in map form ideally represents a synthesis of all available evidence bearing on the palaeogeography of an area for a particular interval of geological time.

There is no question that map representation is the primary tool for palaeogeography (e.g. Feng 2016; Feng et al. 2012). However, complementary to a palaeogeographic map can be an analytical representation of certain palaeogeographic data sets, to expose particular data in a clearly testable way, and provide a guide to new empirical observations required to resolve data conflicts. An example of such representation is the standard 'Apparent Polar Wander Path' (APWP) for palaeomagnetic data, whereby new measurements are tested by the degree to which they conform to a previously established linear pattern (apparent polar wander path).

Quantitative palaeomagnetic data provide evidence of palaeolatitude, as do other qualitative data, for example palaeoclimatic evidence, which could be tested against palaeomagnetism when represented in the same way (first done by Scotese 1986). Palaebiogeographic data may also provide evidence for palaeolatitude, through recognition of cold and warm assemblages, latitudinal diversity gradients, etc., and would also be best analysed using an APWP representation. An early example of this approach was comparison of labyrinthodont amphibian abundance and diversity gradients versus palaeomagnetism as indicators of palaeolatitude for the Late Palaeozoic and Triassic (Irving and Brown 1964).

However, palaeobiogeographic data may also provide a completely different type of evidence, not concerned with palaeolatitude, but instead with the connections or barriers between regions. This is the predominant approach in preceding discussions of this paper. This information has hierarchical structure, and can be analysed 'cladistically'; i.e. using branching diagrams or cladograms (Young 1986). Hierarchical structure is not a special attribute of biogeographic data; rather, it is imposed on the empirical evidence to facilitate analysis and testing of competing hypotheses. The same applies to a range of geological data concerning, for example, past distributions of land and sea, palaeocirculation patterns, or many of the criteria used by geologists to work out a history of accretion for allochthonous terranes, as discussed by Young (1990, 1995b, 2010b).

The evidence of past sea-level fluctuations illustrates how the same data can be represented to facilitate either non-hierachical or hierarchical analysis (Fig. 10). The primary evidence of past sea-level fluctuations derives from lithofacies mapping to distinguish between areas of land and sea for a particular geological time interval (e.g. Feng 2016). However, identifying second- and thirdorder sea-level changes, and distinguishing local (uplift or subsidence) from global effects requires the most detailed biostratigraphic control (e.g. for the Devonian, using conodonts; Mawson and Talent 2000, 2003). Like the curved lines of a palaeomagnetic 'apparent polar wander path', linear (non-hierarchical) representation is standard for a transgression-regression curve (Fig. 10a). But this evidence has implications for reconstruction of barriers or connections between areas (Fig. 10b), and the same information can be transformed into a hierarchical data set, which is then amenable to cladistic analysis (Fig. 10c-d).

Cladistic methods have been applied to analysis of relative timing of collision sequences for palaeocontinental blocks and terranes in the geological past. The first representation of a converging area cladogram in the geological literature (Young 1986) concerned the collision sequence for continental components that came together during the Middle-Late Palaeozoic to form Pangaea. The fusion history of four areas (Laurentia, Baltica, 'Armorica', and Gondwana) was considered as three competing hypotheses, based on a range of geological and geophysical data. It was noted that a similar analysis of four taxa in phylogeny could produce 15 fully resolved and 10 partly resolved cladograms, but for the formation of Pangaea only three out of 25 possible hypotheses of collision history had been considered in the geological literature. The complexity was such that 


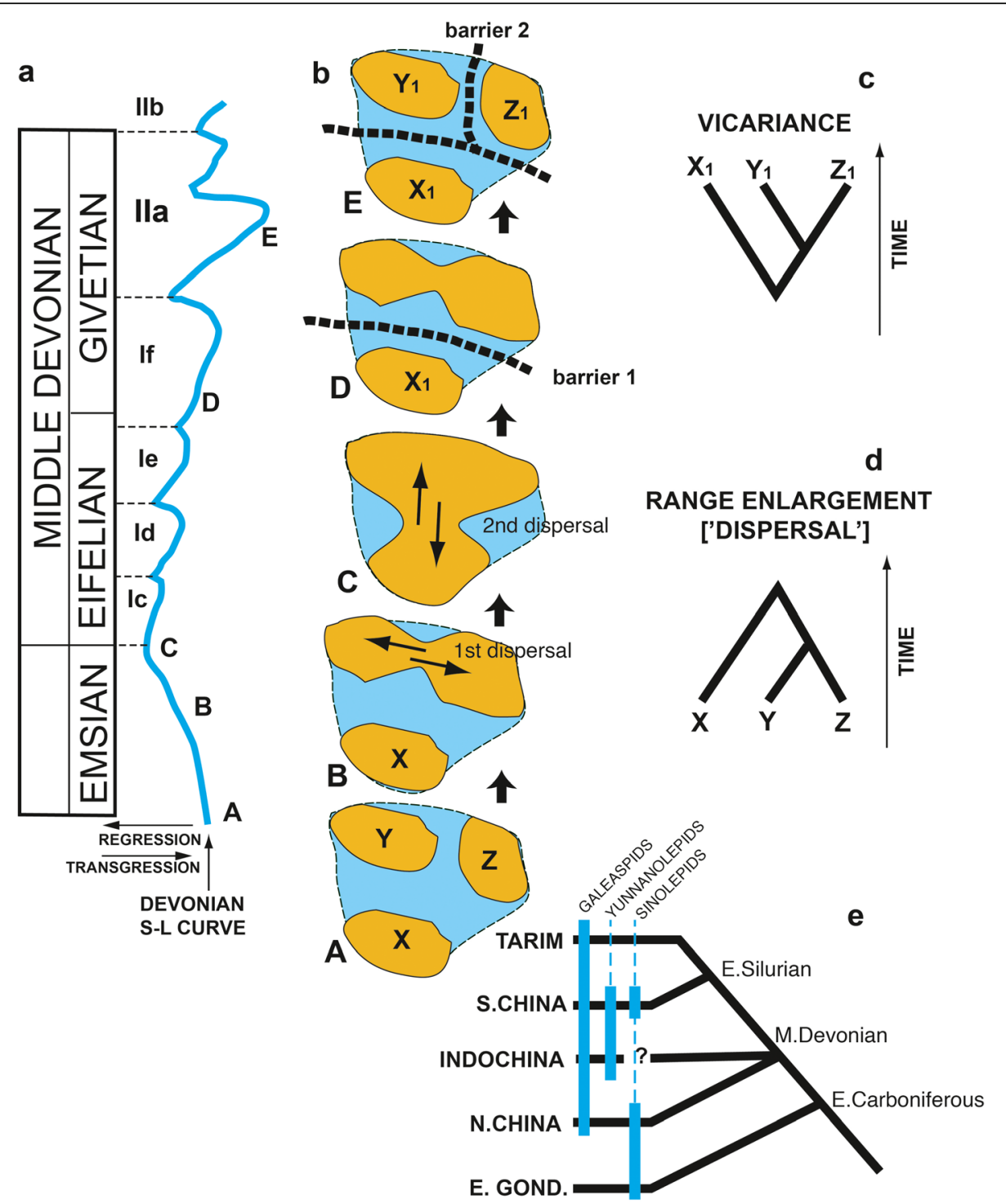

Fig. 10 a-d Alternative representations of a transgression-regression pattern (sea-level curve), using the Early-Middle Devonian (Emsian-Givetian) as an example. a Linear representation (standard sea-level curve); b Marine barriers between three hypothetical continental areas $X, Y, Z$, and dispersal events resulting from sea level fall and rise (letters A-E correspond to positions on sea-level curve in a); $\mathbf{c}$ Hierarchical (cladistic) representation of a vicariance (splitting) pattern in continental faunas resulting from the successive marine barriers; $\mathbf{d}$ Converging (dispersal) pattern in continental faunas resulting from disappearance of marine barriers; e Summary of Siluro-Devonian vertebrate evidence for collision histories of Asian terranes, updated from Young and Janvier (1999). For more detailed discussion see Young (1995b, 2010b) and Young and Janvier (1999)

competing hypotheses could not be adequately represented as maps, but most effectively as six different converging cladograms (Young 1986, fig. 8).

A much more complex collision sequence concerns the collage of geological terranes making up modern Asia, and hypothesised to have originated from Gondwana according to a range of geological and geophysical evidence. Young and Janvier (1999) summarised fossil evidence from some 14 terranes or micro-blocks assumed to have had separate histories according to geological or geophysical evidence. Data from Siluro-
Devonian vertebrate distribution patterns across the region were integrated and summarised as three converging area cladograms (Young and Janvier 1999, fig. 8). The evidence indicates that the Tarim and South China blocks had come together by the Early Silurian, followed by North China and the Indochina terrane by the Middle Devonian (relative timing unresolved), and then connection with East Gondwana by the Early Carboniferous. The distribution of three key endemic Asian vertebrate groups (galeaspid agnathans, and yunnanolepid and sinolepid antiarchs) represented on the cladogram 
(Fig. 10e) predicted the discovery of galeaspids and sinolepids on the Indochina terrane, from which at the time they had not been recorded. Subsequently, Racheboeuf et al. (2006) found galeaspid remains at Ly Hoa in Vietnam, a prediction of the cladistic hypothesis, confirming that Indochina and South China had come together across the Song Ma suture before the Middle Devonian. On available evidence these regions were likely already very close to each other in the Late Silurian and Early Devonian (Wang et al. 2010a), the Indochina terrane being included in the 'Pan-Cathaysian landmass'.

\section{Summary and conclusions}

Early fishes of the Siluro-Devonian were highly mobile organisms, achieving a global distribution in various aquatic environments. However, those forms living in rivers, lakes, and estuaries were largely confined by marine barriers, as evidenced by major taxonomic groupings confined to limited regions. The Late Silurian vertebrate faunas on the South China Block represent one of the most endemic radiations in vertebrate evolutionary history, indicating extreme biogeographic isolation that requires a palaeogeographic explanation.

The highly endemic Devonian fish assemblages of both the Asian region and the eastern Gondwana margin have challenged ideas of early vertebrate evolution based on the fossil assemblages of Europe and North America. Galeaspid agnathans and yunnanolepid and sinolepid antiarch placoderms define the Asian region, and demonstrate close connections between most of the major blocks and terranes making up the collage of modern Asia. Wuttagoonaspid and phyllolepid placoderms define the East Gondwana region, and faunal connections between these regions, indicating palaeogeographic proximity, are indicated by limited similarities in agnathans, basal arthrodires, early tetrapodomorph osteichthyans, and sinolepid antiarchs.

The first evidence of faunal exchange between Asia and East Gondwana is in the Early Devonian (PragianEmsian), but how this and later connections relate to global sea-level transgressions or regressions is still unclear.

In addition, some more widespread groups, that from their distribution patterns must have had better tolerance of marine conditions and evidently could disperse along coastal margins, show disparate temporal-spatial distributions between Asia, Gondwana, and Laurussia. These indicate changing marine tolerances within taxonomic groups, fluctuating connections and barriers due to sea level changes, or both factors combined.

For continental fossil fish assemblages, lacking marine fossils, the age control is much less precise than detailed biozonation (e.g. using conodonts) that is possible for Devonian marine limestones. Nevertheless, the possibility of integrating global sea-level (transgression-regression) curves for the Middle Palaeozoic with changing distribution patterns in Siluro-Devonian fish groups is an area to be explored in future research.

\section{Abbreviation \\ APWP: Apparent Polar Wander Path}

\section{Acknowledgements}

For facilities in the Research School of Physics and Department of Applied Mathematics, ANU, we thank Professors Tim Senden and Adrian Sheppard. We thank Professor Feng Zengzhao for the invitation to contribute and participate in the $4^{\text {th }}$ International Conference of Palaeogeography in Beijing, and Professor Robert Burne (ANU Research School of Earth Sciences) for support. GCY acknowledges visits to China under scientific exchange agreements between the Chinese and Australian Academies of Science. We thank S. Lucas and an anonymous reviewer for helpful comments that greatly improved the manuscript.

\section{Authors' contributions}

$J$ provided text and figures on the osteichthyans; GCY provided text and figures on agnathans, placoderms, biogeography and palaeogeography. Both authors contributed to the final version of the manuscript. The authors read and approved the final manuscript.

\section{Funding}

Research was supported by funding to $J$ under the Strategic Priority Research Program, Chinese Academy of Sciences (Grant No. XDB26000000), and the National Natural Science Foundation of China (41472016). Australian funding was under Australian Research Council Discovery grants DP1092870 and DP140104161. JL was also supported by a Director's strategic postdoctoral fellowship in the ANU Research School of Physics (2016) and the 2018 Marcelja fellowship of the ANU Department of Applied Mathematics.

\section{Availability of data and materials}

Australian specimens illustrated for this study are housed in the Research School of Physics, ANU, Canberra, and the Australian Museum, Sydney. Chinese specimens are housed in the Institute of Vertebrate Paleontology and Paleoanthropology, CAS, Beijing.

\section{Competing interests}

The authors declare that they have no competing interests.

\section{Author details}

'Department of Applied Mathematics, Research School of Physics, Australian National University, Canberra, Australia. ${ }^{2}$ Australian Museum Research Institute, Sydney, Australia. ${ }^{3}$ Key Laboratory of Vertebrate Evolution and Human Origins of Chinese Academy of Sciences, Institute of Vertebrate Paleontology \& Paleoanthropology, Chinese Academy of Sciences, Beijing 10004, China. ${ }^{4}$ CAS Center for Excellence in Life and Paleoenvironment, Beijing 10004, China.

Received: 28 July 2019 Accepted: 6 March 2020

Published online: 07 April 2020

\section{References}

Agassiz, L. 1844. Monographie des poissons fossiles du vieux grès rouge du système Dévonien (Old Red Sandstone) des îles Britanniques et de Russie, 171 pp. Neuchâtel: Jent and Gassmann.

Ahlberg, P.E., and J.A. Clack. 2006. A firm step from water to land. Nature 440 (7085): 747-749.

Ahlberg, P.E., and Z. Johanson. 1997. Second tristichopterid (Sarcopterygii, Osteolepiformes) from the Upper Devonian of Canowindra, New South Wales, Australia, and phylogeny of the Tristichopteridae. Journal of Vertebrate Paleontology 17: 653-673.

Ahmad, M., and T.J. Munson (compilers). 2013. Geology and mineral resources of the Northern Territory, Darwin: Northern Territory Geological Survey, Special Publication 5. 
Ayling, B., J. Huntington, B. Smith, and D. Edwards. 2016. Hyperspectral logging of middle Cambrian marine sediments with hydrocarbon prospectivity: A case study from the southern Georgina Basin, northern Australia. Australian Journal of Earth Sciences 63. https://doi.org/10.1080/ 08120099.2016.1204625.

Berra, T.M. 1981. An atlas of distribution of the freshwater fish families of the world. Nebraska: University of Nebraska Press.

Boger, S.D. 2011. Antarctica-Before and after Gondwana. Gondwana Research 19: 335-371.

Boucot, A.J., C. Scotese, and R.J. Morley. 2013. Phanerozoic paleoclimate: An atlas of lithologic indicators of climate. Society for Sedimentary Geology: Concepts in Sedimentology and Paleontology 11: 1-478.

Burrow, C.J., D.C. Hovestadt, M. Hovestadt-Euler, S. Turner, and G.C. Young. 2008. New information on the Devonian shark Mcmurdodus, based on material from western Queensland, Australia. Acta Geologica Polonica 58: 151-159.

Burrow, C.J., S. Turner, and G.C. Young. 2010. Middle Palaeozoic microvertebrate assemblages and biogeography of east Gondwana (Australasia, Antarctica). Palaeoworld 19: 37-54.

Burrow, C.J., and G.C. Young. 2005. The acanthodian fauna of the Craven Peaks beds (early to middle Devonian), western Queensland. Memoirs of the Queensland Museum 51: 3-25.

Campbell, K.S.W., R.E. Barwick, and T.R. Senden. 2009. Evolution of dipnoans (lungfish) in the early Devonian of southeastern Australia. Alcheringa 33: 59-78.

Chang, K.J. 1963. A new species of Bothriolepis from Kwangtung. Vertebrata PalAsiatica 9: 1-14 [Chinese with English summary].

Chang, M.-M. 1991. Rhipidistians, dipnoans and tetrapods. In Origins of major groups of tetrapods: controversies and consensus, ed. H.-P. Schultze and L. Trueb, 3-28. Ithaca: Cornell University Press.

Chang, M.M., and J.Q. Wang. 1995. A new Emsian dipnorhynchid (Dipnoi) from Guangnan, southeastern Yunnan, China. Geobios, Mémoir Special 19: 233-239.

Chang, M.-M., and X.-B. Yu. 1997. Re-examination of the relationship of middle Devonian osteolepids- Fossil characters and their interpretation. American Museum Novitates 3189: 1-20.

Chang, M.-M., and M. Zhu. 1993. A new middle Devonian osteolepidid from Qujing, Yunnan. Memoir of the Association of Australasian Palaeontologists 15: 183-198.

Clack, J.A. 2007. Devonian climate change, breathing, and the origin of the tetrapod stem group. Integrative and Comparative Biology 47 (4): 510-523.

Clarke, W.B. 1860. Researches in the southern Goldfields of New South Wales. Sydney: Reading and Wellbank, Sydney.

Conybeare, W.D., and W. Phillips. 1822. Outlines of the geology of England and Wales, with an introductory compendium of the general principles of that science, and comparative views of the structure of foreign countries, part 1, $470 \mathrm{pp}$. London: William Phillips.

Draper, J.J. 2013. Belyando Basin. In Geology of Queensland, ed. P.A. Jell, 174175. Brisbane: Geological Survey of Queensland xvi +970 pp.

Duan, L., Q.R. Meng, C.L. Zhang, and X.M. Liu. 2011. Tracing the position of the South China block in Gondwana: U-Pb ages and Hf isotopes of Devonian detrital zircons. Gondwana Research 19: 141-149.

Dupret, V. 2008. A new wuttagoonaspid (Placodermi, Arthrodira) from the Lower Devonian of Yunnan (South China): Origin, dispersal, and paleobiogeographic significance. Journal of Vertebrate Paleontology 28: 12-20.

Dupret, V., and M. Zhu. 2008. The earliest phyllolepid (Placodermi, Arthrodira) from the late Lochkovian (Early Devonian) of Yunnan (South China). Geological Magazine 145: 257-278.

Eichwald, E.I. 1840. Die Thier- und Pflanzenreste des alten rothen Sandsteins und Bergkalks im Novgorodschen Gouvernment. Bulletin of the Academy of Sciences, St Petersburg 7: 78-91.

Feng, Z.Z. 2016. On palaeogeographic map. Journal of Palaeogeography 5(1): $1-27$.

Feng, Z.Z., X.J. Zheng, and Z.K. Jin. 2012. Palaeogeography of China. Journal of Palaeogeography 1(1): 91-104.

Friedman, M., and M.D. Brazeau. 2010. A reappraisal of the origin and basal radiation of the Osteichthyes. Journal of Vertebrate Paleontology 30: 36-56.
Friedman, M., and M.D. Brazeau. 2011. Sequences, stratigraphy and scenarios: What can we say about the fossil record of the earliest tetrapods? Proceedings of the Royal Society B: Biological Sciences 278 (1704): 432-439. https://doi.org/10.1098/rspb.2010.1321.

George, D., and A. Blieck. 2011. Rise of the earliest tetrapods: An Early Devonian origin from marine environment. PLoS One 6 (7): e22136. https://doi.org/10.1371/ journal.pone.0022136.

Henderson, R.A., I.W. Withnall, and P.A. Jell. 2013. Ukalunda Shelf. In Geology of Queensland, ed. P.A. Jell, 171-174. Brisbane: Geological Survey of Queensland xvi +970 pp.

Hills, E.S. 1936. On certain endocranial structures in Coccosteus. Geological Magazine 73: 213-226.

Huang, B., Y. Yan, J.D.A. Piper, D. Zhang, Z. Yi, S. Yu, and T. Zhou. 2018. Paleomagnetic constraints on the paleogeography of the east Asian blocks during late Palaeozoic and early Mesozoic times. Earth-Science Reviews 186: 8-36.

Hunt, J.R., and G.C. Young. 2011. A new placoderm fish of uncertain affinity from the early-middle Devonian Hatchery Creek succession at Wee Jasper, New South Wales. Alcheringa 35: 53-75. https://doi.org/10.1080/ 03115511003793645.

Hunt, J.R., and G.C. Young. 2012. Depositional environment, stratigraphy, structure, and palaeobiology of the Hatchery Creek group (early?middle Devonian) near Wee Jasper, New South Wales. Australian Journal of Earth Sciences 59: 355-371.

Hurley, N.F., and R. Van Der Voo. 1987. Paleomagnetism of upper Devonian reefal limestones, Canning Basin, Western Australia. Geological Society of America, Bulletin 98: 138-146.

Irving, E., and D.A. Brown. 1964. Abundance and diversity of labyrinthodonts as a function of paleolatitude. American Journal of Science 262: 689-708.

Janvier, P. 1996. Early vertebrates, 393 pp. Oxford: Clarendon Press.

Janvier, P., P. Racheboeuf, H.N. Huu, and T.D. Nhat. 2003. Devonian fish (Placodermi, Antiarcha) from Tra Ban Island (Bai Tu Long Bay, Quang Ninh Province, Vietnam) and the question of the age of the Do Son Formation. Journal of Asian Earth Sciences 21: 795-801.

Janvier, P., T.-D. Thanh, T.H. Phuong, G. Clement, and N.D. Phong. 2009. Occurrence of Sanqiaspis, Liu, 1975 (Vertebrata, Galeaspida) in the lower Devonian of Vietnam, with remarks on the anatomy and systematics of the Sanqiaspididae. Comptes Rendus Palevol 8: 59-65.

Johanson, Z., and P.E. Ahlberg. 2001. Devonian rhizodontids and tristichopterids (Sarcopterygii: Tetrapodomorpha) from East Gondwana. Transactions of the Royal Society of Edinburgh, Earth Sciences 92: 43-74.

Lelièvre, H., M.S. Al-Muallen, D. Goujet, M. Halewani, D. Janjou, P. Janvier, and C. Robelin. 1999. Early Devonian vertebrates from the Jauf Formation Saudi Arabia, 26 pp. Saudi Arabian Deputy Ministry for Mineral Resources Technical Report BRGM-TR-13-5.

Li, Z.X., and C.M. Powell. 2001. An outline of the palaeogeographic evolution of the Australasian region since the beginning of the Neoproterozoic. Earth-Science Reviews 53: 237-277.

Liu, S.F. 1973. New materials of Bothriolepis shaokuanensis and the age of the fish bearing beds. Vertebrata PalAsiatica 11: 36-42 (in Chinese with English summary).

Liu, T.S., and K. Pan. 1958. Devonian fishes from Wutung Series near Nanking, China. Palaeontologica Sinica 141 (new series C 15): 1-41 (in Chinese and English).

Liu, Y.H. 1963. On the Antiarchi from Chutsing, Yunnan. Vertebrata PalAsiatica 7: 39-46 (in Chinese with English summary).

Liu, Y.-H. 1965. New Devonian agnathans of Yunnan. Vertebrata PalAsiatica 9: 125-134 (in Chinese with English summary).

Long, J.A. 1984. New phyllolepids from Victoria, and the relationships of the group. Proceedings of the Linnean Society of New South Wales 107: 263-308.

Long, J.A., ed. 1993. Palaeozoic vertebrate biostratigraphy and biogeography, 369 pp. London: Belhaven Press.

Long, J.A., E. Mark-Kurik, and G.C. Young. 2014. Taxonomic revision of buchanosteoid placoderms (Arthrodira) from the early Devonian of SouthEastern Australia and Arctic Russia. Australian Journal of Zoology 62: 26-43.

Long, J.A., S. Turner, and G.C. Young. 1988. A Devonian fish fauna from subsurface sediments in the eastern Officer Basin, South Australia. Alcheringa 12: 61-78. 
Lu, J., and M. Zhu. 2008. An early Devonian (Pragian) sarcopterygian from Zhaotong, Yunnan, China. Vertebrata PalAsiatica 46: 161-170.

Lu, J., M. Zhu, J.A. Long, W. Zhao, T.J. Senden, L. Jia, and T. Qiao. 2012. The earliest known stem-tetrapod from the Lower Devonian of China. Nature Communications 3: 1160. https://doi.org/10.1038/ncomms2170.

Lu, J., Y. Zhu, and M. Zhu. 2016. From fish to human: Origin and early evolution of osteichthyans. Chinese Journal of Nature 38 (6): 391-398.

Lucas, S.G. 2015. Thinopus and a critical review of Devonian tetrapod footprints. Ichnos 22: 136-154.

Ma, X.P., W. Liao, and D. Wang. 2009. The Devonian system of China, with a discussion of sea-level change in South China. Geological Society of London, Special Publications 314: 241-262.

Mansuy, H. 1907. Resultats paleontologiques. In Resultats de la mission géologique et miniere du Yunnan méridional (Septembre 1903-Janvier 1904), ed. M.H. Lantenois, 150-177. Paris: Dunod and Pinat.

Mansuy, H. 1915. Contribution a l'etude des faunes de Ordovicien et du Gothlandien du Tonkin. Mémoires du Service Géologique de I'Indochine 4: $1-322$.

Mark-Kurik, E., and G.C. Young. 2003. A new buchanosteid arthrodire (placoderm fish) from the early Devonian of the Ural Mountains. Journal of Vertebrate Paleontology 23: 13-27.

Mawson, R., and J.A. Talent. 2000. The Devonian of eastern Australia. Stratigraphic alignments, stage and series boundaries, and the transgression-regression pattern reconsidered. Courier Forschungsinstitut Senckenberg 225: 243-270.

Mawson, R., and J.A. Talent. 2003. Conodont faunas from sequences on or marginal to the Anakie inlier (Central Queensland, Australia) in relation to Devonian transgressions. Bulletin of Geosciences (Czech Geological Survey) 87: 335-358.

McElhinney, M.W., C.McA. Powell, and S.A. Pisarevsky. 2003. Paleozoic terranes of eastern Australia and the drift history of Gondwana. Tectonophysics 362: 41-65.

McKillop, M.D. 2013. Adavale Basin. In Geology of Queensland, ed. P.A. Jell, 175-183. Brisbane: Geological Survey of Queensland xvi + 970 pp.

Metcalfe, I. 1996a. Pre-Cretaceous evolution of SE Asian terranes. Geological Society of London, Special Publications 106: 97-122.

Metcalfe, I. 1996b. Gondwanaland dispersion, Asian accretion and evolution of eastern Tethys. Australian Journal of Earth Sciences 43: 605-623.

Metcalfe, I. 2013. Gondwana dispersion and Asian accretion: Tectonic and palaeogeographic evolution of eastern Tethys. Journal of Asian Earth Science 66: 1-33.

Miles, R.S. 1971. Palaeozoic fishes. 2nd ed, 259 pp. London: Chapman and Hall.

Murchison, R.I. 1839. The Silurian system, 768 pp. London: J. Murray.

Niedźwiedzki, G., P. Szrek, K. Narkiewicz, M. Narkiewicz, and P.E. Ahlberg. 2010. Tetrapod trackways from the early middle Devonian period of Poland. Nature 463 (7277): 43-48.

Pan, K. 1964. On some Devonian and Carboniferous fishes from South China. Acta Paleontologica Sinica 12: 139-168 (in Chinese with English summary).

Pan, J. 1992. New galeaspids (Agnatha) from the Silurian and Devonian of China. 77 pp. Beijing: Geological Publishing House.

P'an, K., S.T. Wang, and Y.P. Liu. 1975. The lower Devonian Agnatha and Pisces from South China, 135-169. Beijing: Professional Papers in Palaeontology and Stratigraphy [in Chinese].

Pan, J., F.C. Huo, J.X. Cao, Q.C. Gu, S.Y. Liu, J.Q. Wang, L.D. Gao, and C. Liu. 1987. Continental Devonian System of Ningxia and its Biotas, 237 pp. Beijing: Geological Publishing House.

Pan, Z.-H., M. Zhu, Y.-A. Zhu, and L.-T. Jia. 2017. A new antiarch placoderm from the Emsian (Early Devonian) of Wuding, Yunnan, China. Alcheringa. https://doi.org/10.1080/03115518.2017.1338357.

Qiao, T., and M. Zhu. 2015. A new Early Devonian lungfish from Guangxi, China, and its palaeogeographic significance. Alcheringa 39: 428-437.

Racheboeuf, P., P. Janvier, T.H. Phuong, J. Vannier, and S.Q. Wang. 2005. Lower Devonian vertebrates, arthropods and brachiopods from northern Vietnam. Geobios 38: 533-551.

Racheboeuf, P., T.H. Phuong, N. Huu Hung, M. Feist, and P. Janvier. 2006. Brachiopods, crustaceans, vertebrates and charyophytes from the
Devonian Ly Hoa, Nam Can and Dong Tho Formations of central Vietnam. Geodiversitas 28: 5-36.

Randall, R.E. 2013. Petroleum. In Geology of Queensland, ed. P.A. Jell, 739749. Brisbane: Geological Survey of Queensland xvi +970 pp.

Ritchie, A. 1973. Wuttagoonaspis gen. nov., an unusual arthrodire from the Devonian of Western New South Wales, Australia. Palaeontographica A 143: 58-72.

Ritchie, A. 1984. A new placoderm, Placolepis gen. nov. (Phyllolepidae) from the late Devonian of New South Wales, Australia. Proceedings of the Linnean Society of New South Wales 107: 321-353.

Ritchie, A. 2004. A new genus and two new species of groenlandaspidid arthrodire (Pisces, Placodermi) from the Early-Middle Devonian Mulga downs group of western New South Wales, Australia. In: Young, G.C. (Ed.) Proceedings of Symposium 6 (Palaeozoic vertebrates): First International Palaeontological Congress (IPC 2002). Sydney, Australia, July 2002. Fossils and Strata 50: 56-81.

Ritchie, A. 2005. Cowralepis, a new genus of phyllolepid fish (Pisces, Placodermi) from the late middle Devonian of New South Wales, Australia. Proceedings of the Linnean Society of New South Wales 125: 215-259.

Ritchie, A., S.T. Wang, G.C. Young, and G.R. Zhang. 1992. The Sinolepidae, a family of antiarchs (placoderm fishes) from the Devonian of South China and eastern Australia. Records of the Australian Museum 44: 319-370.

Rosen, D.E. 1974. Phylogeny and zoogeography of salmoniform fishes Bulletin of the American Museum of Natural History 153: 265-326.

Rudwick, M.J.S. 1985. The great Devonian controversy, 494 pp. University of Chicago Press.

Scotese, C.R. 1986. Phanerozoic reconstructions: A new look at the assembly of Asia. University of Texas Institute for Geophysics, Technical Report 66: 1-54.

Sedgwick, A., and R.I. Murchison. 1839. Classification of the older stratified rocks of Devonshire and Cornwall. London and Edinburgh Philosophical Magazine, Series 3 (14): 241-260.

Sprigg, R.C. 1963. Geology and petroleum prospects of the Simpson Desert. Transactions of the Royal Society of South Australia 86: 35-65.

Stensiö, E. 1945. On the heads of certain arthrodires. II. On the cranium and cervical joint of the Dolichothoracids (Acanthaspida). Kungliga Svenska Vetenskapsakademiens Handlingar 22: 1-70.

Stensiö, E.A. 1948. On the Placodermi of the Upper Devonian of East Greenland. 2. Antiarchi: Subfamily Bothriolepinae. With an attempt at a revision of the previous described species of that family. Meddelelser om Grønland 139: 1-622.

Struckmeyer, H.I.M., and J.M. Totterdell. 1990. Australia: Evolution of a continent, 97. Australia: Bureau of Mineral Resources.

Tong-Dzuy, T., P. Janvier, and P. Ta Hoa. 1996. Fish suggests continental connections between the Indochina and South China blocks in Middle Devonian time. Geology 24: 571-574.

Turner, S. 1995. Devonian thelodont scales (Agnatha, Thelodonti) from Queensland. Memoirs of the Queensland Museum 38: 677-685.

Turner, S. 1997. Sequence of Devonian thelodont scale assemblages in East Gondwana. Geological Society of America, Special Publications 32: 295-315.

Turner, S., P.J. Jones, and J.J. Draper. 1981. Early Devonian thelodonts (Agnatha) from the Toko Syncline, western Queensland, and a review of other Australian discoveries. BMR Journal of Australian Geology and Geophysics 6: 51-69.

Turner, S., and G.C. Young. 1987. Shark teeth from the Early-Middle Devonian Cravens Peak beds, Georgina Basin, Queensland. Alcheringa 11: 233-244.

Verard, C., C. Hochard, P.O. Baumgartner, and G.M. Stampfli. 2015. Geodynamic evolution of the earth over the Phanerozoic: Plate tectonic activity and palaeoclimatic indicators. Journal of Palaeogeography 4: 167-188.

Walley, A.M., and P.J. Cook. 1991. The Palaeozoic palaeogeography of the Amadeus Basin region. In Geological and geophysical studies in the Amadeus Basin, central Australia, ed. R.J. Korsch and J.M. Kennard, 155169. Australia: Bureau of Mineral Resources Bulletin 236, 594 pp.

Wang, H.C. 1943. The stratigraphic position of the Devonian fish-bearing series (Bothriolepis bed) of eastern Yunnan. Science Record 1: 562-564. 
Wang, J.Q. 2005. New material of Buchanosteus and its biostratigraphic significance. Geological Bulletin of China 24: 800-806.

Wang, S.Q. 1983. Ostracods from the Devonian Sipai Formation of Guangxi. Memoir of the Nanjing Institute of Geology and Palaeontology 18: 111154 (in Chinese with English abstract).

Wang, S.T., V. Drapala, R.E. Barwick, and K.S.W. Campbell. 1993. The dipnoan species, Sorbitorhynchus deleaskitus, from the Lower Devonian of Guangxi, China. Philosophical Transactions of the Royal Society B340: 1-24.

Wang, S.T., J. Pan, and J.Q. Wang. 1998. Early Devonian fishes from central and southern Guangxi and correlation of the vertebrate biostratigraphy in South China. Vertebrata PalAsiatica 36: 58-69 (in Chinese with English summary).

Wang, W., Q.M. Qu, and M. Zhu. 2010a. A brief review of the Middle Palaeozoic vertebrates from Southeast Asia. Palaeoworld 19: 27-36.

Wang, Y., F. Zhang, W. Fan, G. Zhang, S. Chen, P.A. Cawood, and A. Zhang. 2010b. Tectonic setting of the South China Block in the early Paleozoic: Resolving intracontinental and ocean closure models from detrital zircon U-Pb geochronology. Tectonics 29: TC6020. https://doi.org/10. 1029/2010TC002750.

Wang, Y., and M. Zhu. 2018. Redescription of Phymolepis cuifengshanensis (Antiarcha: Yunnanolepididae) using high-resolution computed tomography and new insights into anatomical details of the endocranium of antiarchs. PeerJ 6: e4808. https://doi.org/10.7717/peerj. 4808.

Warren, A., R. Jupp, and B. Bolton. 1986. Earliest tetrapod trackway. Alcheringa 10: 183-186.

Webb, G.E. 2000. The palaeobiogeography of eastern Australian Lower Carboniferous corals. Historical Biology 15: 91-117.

Wilford, G.E., and S. Olissoff. 1990. Devonian. In BMR Palaeogeographic group 1990 -- Australia: Evolution of a continent, 97 pp. Canberra: Bureau of Mineral Resources.

Woodward, A.S. 1916. On Devonian fish-remains from Australia and the Antarctic regions. Proceedings of the Geological Society of London 72: 79-80.

Woodward, A.S. 1921. Fish-remains from the Upper Old Red Sandstone of Granite Harbour, Antarctica. British Antarctic (Terra Nova) Expedition, 1910. Natural History Report (Geology) 1: 51-62.

Yang, Z., Z. Sun, T. Yang, and J. Pei. 2004. A long connection (750-380 Ma) between South China and Australia: Paleomagnetic constraints. Earth and Planetary Science Letters 220: 423-434.

Young, B., R.L. Dunstone, T.J. Senden, and G.C. Young. 2013. A gigantic sarcopterygian (tetrapodomorph lobe-finned fish) from the Upper Devonian of Gondwana (Eden, New South Wales, Australia). PLoS One 8 (3): e53871.

Young, G.C. 1979. New information on the structure and relationships of Buchanosteus (Placodermi: Euarthrodira) from the Early Devonian of New South Wales. Zoological Journal of the Linnean Society of London 66: 309-352.

Young, G.C. 1980. A new Early Devonian placoderm from New South Wales, Australia, with a discussion of placoderm phylogeny. Palaeontographica A 167: 10-76.

Young, G.C. 1981. Biogeography of Devonian vertebrates. Alcheringa 5: 225-243.

Young, G.C. 1984. An asterolepidoid antiarch (placoderm fish) from the Early Devonian of the Georgina Basin, Central Australia. Alcheringa 8: 65-80.

Young, G.C. 1986. Cladistic methods in Paleozoic continental reconstruction. Journal of Geology 94: 523-537.

Young, G.C. 1988. Antiarchs (placoderm fishes) from the Devonian Aztec Siltstone, southern Victoria land, Antarctica. Palaeontographica A 202: 1-125.

Young, G.C. 1990. Devonian vertebrate distribution patterns, and cladistic analysis of palaeogeographic hypotheses. McKerrow, W.S., Scotese, C.R. (Eds.), Palaeozoic palaeogeography and biogeography. Geological Society of London Memoir 12: 243-255.

Young, G.C. 1991. The first armoured agnathan vertebrates from the Devonian of Australia. In Early vertebrates and related problems of evolutionary biology, ed. M.M. Chang, Y.H. Liu, and G.R. Zhang, 67-85. Beijing: Science Press.

Young, G.C. 1993. Middle Palaeozoic macrovertebrate biostratigraphy of eastern Gondwana. In Palaeozoic vertebrate biostratigraphy and biogeography, ed. J.A. Long, 208-251. London: Belhaven Press.
Young, G.C. 1995a. Early vertebrates and palaeogeographic models. Geobios 19: 129-134.

Young, G.C. 1995b. Application of cladistics to terrane history - Parsimony analysis of qualitative geological data. Journal of Southeast Asian Earth Sciences 11: 167-176.

Young, G.C. 1996. Devonian (chart 4). In An Australian Phanerozoic timescale, ed. G.C. Young and J.R. Laurie, 96-109. Melbourne: Oxford University Press.

Young, G.C. 1999. Preliminary report on the biostratigraphy of new placoderm discoveries in the Hervey Group (upper Devonian) of Central New South Wales. Records of the Western Australian Museum, Supplement 57: 139-150.

Young, G.C. 2003. North Gondwana mid-Palaeozoic connections with Euramerica and Asia: Devonian vertebrate evidence. Courier Forschungsinstitut Senckenberg 242: 169-185.

Young, G.C. 2005a. An articulated phyllolepid fish (Placodermi) from the Devonian of Central Australia: Implications for non-marine connections with the Old Red Sandstone continent. Geological Magazine 142: 173-186.

Young, G.C. 2005b. A new phyllolepid placoderm occurrence (Devonian fish) from the Dulcie Sandstone, Georgina Basin, Central Australia. Proceedings of the Linnean Society of New South Wales 126: 203-213.

Young, G.C. 2005c. New phyllolepids (placoderm fishes) from the Middlelate Devonian of southeastern Australia. Journal of Vertebrate Paleontology 25: 261-273.

Young, G.C. 2006. Biostratigraphic and biogeographic context for tetrapod origins during the Devonian: Australian evidence. In: Reed, L., Bourne, S. Megirian, D., Prideaux, G., Young, G., Wright, A. (Eds.), Proceedings of CAVEPS 2005. Alcheringa 30 (Special Issue 1): 409-428.

Young, G.C. 2007. Devonian formations, vertebrate faunas and age control on the far south coast of New South Wales and adjacent Victoria. Australian Journal of Earth Sciences 54: 991-1008.

Young, G.C. 2008. Relationships of tristichopterids (osteolepiform lobefinned fishes) from the Middle-Late Devonian of East Gondwana. Alcheringa 32: 321-336.

Young, G.C. 2010a. Placoderms (armored fish): Dominant vertebrates of the Devonian period. Annual Review of Earth and Planetany Sciences 38: 523-550.

Young, G.C. 2010b. Analytical methods in palaeobiogeography, and the role of early vertebrate studies. Palaeoworld 19: 160-173.

Young, G.C., C.B. Burrow, J.A. Long, S. Turner, and B. Choo. 2010. Devonian macrovertebrate assemblages and biogeography of East Gondwana (Australasia, Antarctica). Palaeoworld 19: 55-74.

Young, G.C., R.L. Dunstone, P.J. Ollerenshaw, J. Lu, and B. Crook. 2019. New information on the giant Devonian lobe-finned fish Edenopteron from the New South Wales south coast. Australian Journal of Earth Sciences. https://doi.org/10.1080/08120099.2019.1651769.

Young, G.C., and J.D. Gorter. 1981. A new fish fauna of Middle Devonian age from the Taemas/Wee Jasper region of New South Wales. Bulletin, Bureau of Mineral Resources, Geology and Geophysics 209: 83-147.

Young, G.C., and D. Goujet. 2003. Devonian fish remains from the Dulcie Sandstone and Cravens Peak beds, Georgina Basin, Central Australia. Records of the Western Australian Museum, Supplement 65: 1-85.

Young, G.C., and P. Janvier. 1999. Early-middle Palaeozoic vertebrate faunas in relation to Gondwana dispersion and Asian accretion. In Gondwana dispersion and Asian accretion. IGCP 321 final results volume, ed. I. Metcalfe, J.S. Ren, J. Charvet, and S. Hada, 115-140. Rotterdam: A.A. Balkema.

Young, G.C., and J.A. Long. 2005. Phyllolepid placoderm fish remains from the Devonian Aztec Siltstone, southern Victoria Land, Antarctica. Antarctic Science 17: 387-408.

Young, G.C., and J.A. Long. 2014. New arthrodires (placoderm fishes) from the Aztec Siltstone (late Middle Devonian) of southern Victoria Land, Antarctica. Australian Journal of Zoology 62: 44-62.

Young, G.C., J.A. Long, and A. Ritchie. 1992. Crossopterygian fishes from the Devonian of Antarctica: Systematics, relationships and biogeographic significance. Records of the Australian Museum, Supplement 14: 1-77.

Young, G.C., and H.P. Schultze. 2005. New osteichthyans (bony fishes) from the Devonian of Central Australia. Mitteilungen aus dem Museum für Naturkunde in Berlin, Geowissenschaftliche Reihe 8: 13-35. 
Young, G.C., and S. Turner. 2000. Devonian microvertebrates and marinenonmarine correlation in East Gondwana: Overview. In: Blieck, A., Turner, S. (Eds.), Palaeozoic vertebrate biochronology and global marine/nonmarine correlation. Final report of IGCP 328 (1991-1996). Courier Forschungsinstitut Senckenberg 223: 453-470.

Zhang, G.R., and Y.G. Liu. 1991. A new antiarch from the Upper Devonian of Jiangxi, China. In Early vertebrates and related problems of evolutionary biology, ed. M.M. Chang, Y.H. Liu, and G.R. Zhang, 195-212. Beijing: Science Press.

Zhang, G.R., and G.C. Young. 1992. A new antiarch (placoderm fish) from the Early Devonian of South China. Alcheringa 16: 219-240.

Zhao, W.J., and M. Zhu. 2007. Diversification and faunal shift of SiluroDevonian vertebrates of China. Geological Journal 42: 351-369.

Zhao, W.J., and M. Zhu. 2010. Siluro-Devonian vertebrate biostratigraphy and biogeography of China. Palaeoworld 19: 4-26.

Zhao, X., R.S. Coe, S.A. Gilder, and G.M. Frost. 1996. Palaeomagnetic constraints on the palaeogeography of China: Implications for Gondwanaland. Australian Journal of Earth Sciences 43: 643-672.

Zhu, M. 2000. Catalogue of Devonian vertebrates in China, with notes on bio-events. In: Blieck, A., Turner, S. (Eds.), Palaeozoic vertebrate biochronology and global marine/non-marine correlation. Final report of IGCP 328 (1991-1996). Courier Forschungsinstitut Senckenberg 223: 373-390.

Zhu, M., P.E. Ahlberg, B. Choo, J. Lu, T. Qiao, Q.M. Qu, W.J. Zhao, L.T. Jia, H. Blom, and Y.A. Zhu. 2013. A Silurian placoderm with osteichthyan-like marginal jawbones. Nature 502: 188-193. https://doi.org/10.1038/ nature12617.

Zhu, M., P.E. Ahlberg, Z.H. Pan, Y.A. Zhu, T. Qiao, W.J. Zhao, L.T. Jia, and J. Lu. 2016. A Silurian maxillate placoderm illuminates jaw evolution. Science 354 (6310): 334-336.

Zhu, M., N. Wang, and J. Wang. 2000. Devonian macro- and microvertebrate assemblages of China. In: Blieck, A., Turner, S. (Eds.), Palaeozoic vertebrate biochronology and global marine/non-marine correlation. Final report of IGCP 328 (1991-1996). Courier Forschungsinstitut Senckenberg 223: 361-372.

Zhu, M., and G.C. Young (eds). 2010. Special issue: Middle Palaeozoic vertebrate biogeography, palaeogeography and climate (IGCP 491). Palaeoworld 19, issues 1-2 (205).

Zhu, M., W.J. Zhao, L.T. Jia, J. Lu, T. Qiao, and Q.M. Qu. 2009. The oldest articulated osteichthyan reveals mosaic gnathostome characters. Nature 458: 469-474.

Ziegler, A.M., D.B. Rowley, A.L. Lottes, D.L. Sahagian, M.L. Hulver, and T.C. Gierlowski. 1985. Paleogeographic interpretation: With an example from the mid-Cretaceous. Annual Review of Earth and Planetary Sciences 13: 385-425.

\section{Publisher's Note}

Springer Nature remains neutral with regard to jurisdictional claims in published maps and institutional affiliations.

\section{Submit your manuscript to a SpringerOpen ${ }^{\circ}$ journal and benefit from:}

- Convenient online submission

- Rigorous peer review

- Open access: articles freely available online

- High visibility within the field

- Retaining the copyright to your article

Submit your next manuscript at $\boldsymbol{\nabla}$ springeropen.com 